\title{
17. MESOZOIC RADIOLARIA IN THE ATLANTIC OCEAN OFF THE NORTHWEST COAST OF AFRICA, DEEP SEA DRILLING PROJECT, LEG 41
}

\author{
Helen P. Foreman, Oberlin College, Oberlin, Ohio
}

\begin{abstract}
Radiolaria from Hole 367 (Neocomian/Late Jurassic) and Hole 396A (Late Cretaceous) are described and their occurrences and abundances tabulated. Previously established ranges for some of the taxa are refined, and from Hole 369A, six new species and two new subspecies are described.
\end{abstract}

\section{TABLE OF CONTENTS}

$\begin{array}{ll}\text { Abstract } & 739 \\ \text { Introduction } & 739 \\ \text { Presentation of Results } & 739 \\ \text { Zonation } & 740 \\ \text { Phylogeny } & 740 \\ \text { Radiolaria from Each Site } & 740 \\ \text { Hole 367 with Table 1 } & 740 \\ \text { Hole 368 } & 742 \\ \text { Hole 369A with Table 2 } & 742 \\ \text { Systematic Section } & 742 \\ \text { Spumellaria } & 742 \\ \text { Family Actinommidae } & 742 \\ \text { Subfamily Saturnalinae } & 744 \\ \text { Family Phacodiscidae } & 744 \\ \text { Family Phaseliformidae } & 744 \\ \text { Family Pseudoaulophacidae } & 744 \\ \text { Family Spongodiscidae } & 744 \\ \text { Family Sponguridae } & 745 \\ \text { Nassellaria } & 745 \\ \text { Family Amphipyndacidae } & 745 \\ \text { Family Artostrobiidae } & 745 \\ \text { Family Parvicingulidae } & 746 \\ \text { Family Theoperidae } & 746 \\ \text { Subfamily Syringocapsinae } & 748 \\ \text { Radiolaria of Uncertain Affinities } & 749 \\ \text { Acknowledgments } & 750 \\ \text { References } & 750\end{array}$

\section{INTRODUCTION}

Radiolaria of Mesozoic age have been investigated from two of the five sites that were drilled on Leg 41. Their positions are as follows: Site 367, Cape Verde Basin, $12^{\circ} 29.2^{\prime} \mathrm{N}, 20^{\circ} 02.8^{\prime} \mathrm{W}$ at a water depth of 4748 meters; Site 369, continental slope off the Spanish Sahara, $26^{\circ} 35.5^{\prime} \mathrm{N}, 14^{\circ} 59.9^{\prime} \mathrm{W}$. Mesozoic Radiolaria at Site 367 are Neocomian/Late Jurassic in age and at Site 369 Maestrichtian/Campanian.

Although Holes 368 and 370 sampled Cretaceous sediments, Radiolaria, when present, were so rare or poorly preserved that no systematic investigation of samples was made from these two holes. In Hole 366 scrapings from the core catcher of the lowest Core 55 were considered to be Cretaceous (Maestrichtian). No sample was available and the shipboard scientists do not mention finding Radiolaria in it.

\section{PRESENTATION OF RESULTS}

For the Mesozoic sequences in Hole 367, Cores 29-37 (Table 1), and Hole 369A, Cores 35-39 (Table 2) radiolarian occurrences and abundances have been tabulated and the Radiolaria arranged in stratigraphic order as far as it was possible. The poor preservation in Hole 367 and the paucity and short sequence in Hole $369 \mathrm{~A}$ limit somewhat the usefulness of this arrangement. Therefore, for Hole 367 when outside evidence indicates a longer range than the one presented in this material, an arrow indicates the direction of the more extended range. For Hole 369A additional outside evidence has been used in arranging the sequence of species. Here too, arrows indicate outside evidence for more extended ranges than those suggested by the table.

Letters and footnotes to the tables are defined as follows:

$\begin{array}{ll}\text { G } & \text { Good } \\ \text { M } & \text { Moderate } \\ \text { P } & \text { Poor } \\ - & \text { Looked for but not found } \\ + & \text { Two specimens } \\ \text { - } & \text { One specimen } \\ \triangle & \text { Porcellanite } \\ \text { A } & \text { Abundant } \\ \text { C } & \text { Common } \\ \text { F } & \text { Few } \\ \text { R } & \text { Rare } \\ \text { VR } & \text { Very rare } \\ \text { P } & \begin{array}{l}\text { Present, but recognized with such difficulty } \\ \text { that no estimate of abundance could be made. }\end{array} \\ \text { ? } & \text { Uncertain identification } \\ \text { a } \quad \begin{array}{l}\text { Without the complete spine it is not possible to } \\ \text { distinguish these two species when they co- }\end{array} \\ \quad \begin{array}{l}\text { occur and a (?) indicates this uncertainty. } \\ \text { Absences are not noted because they may be }\end{array} \\ \text { due to poor preservation. } \\ \text { c Age assignments are made according to } \\ & \begin{array}{l}\text { information provided by nannofossils and } \\ \text { foraminifers recorded elsewhere in this volume. }\end{array}\end{array}$


TABLE

Occurrence and Abundance of Neocomian/Late Jurassic Radiolarians of Hole 367

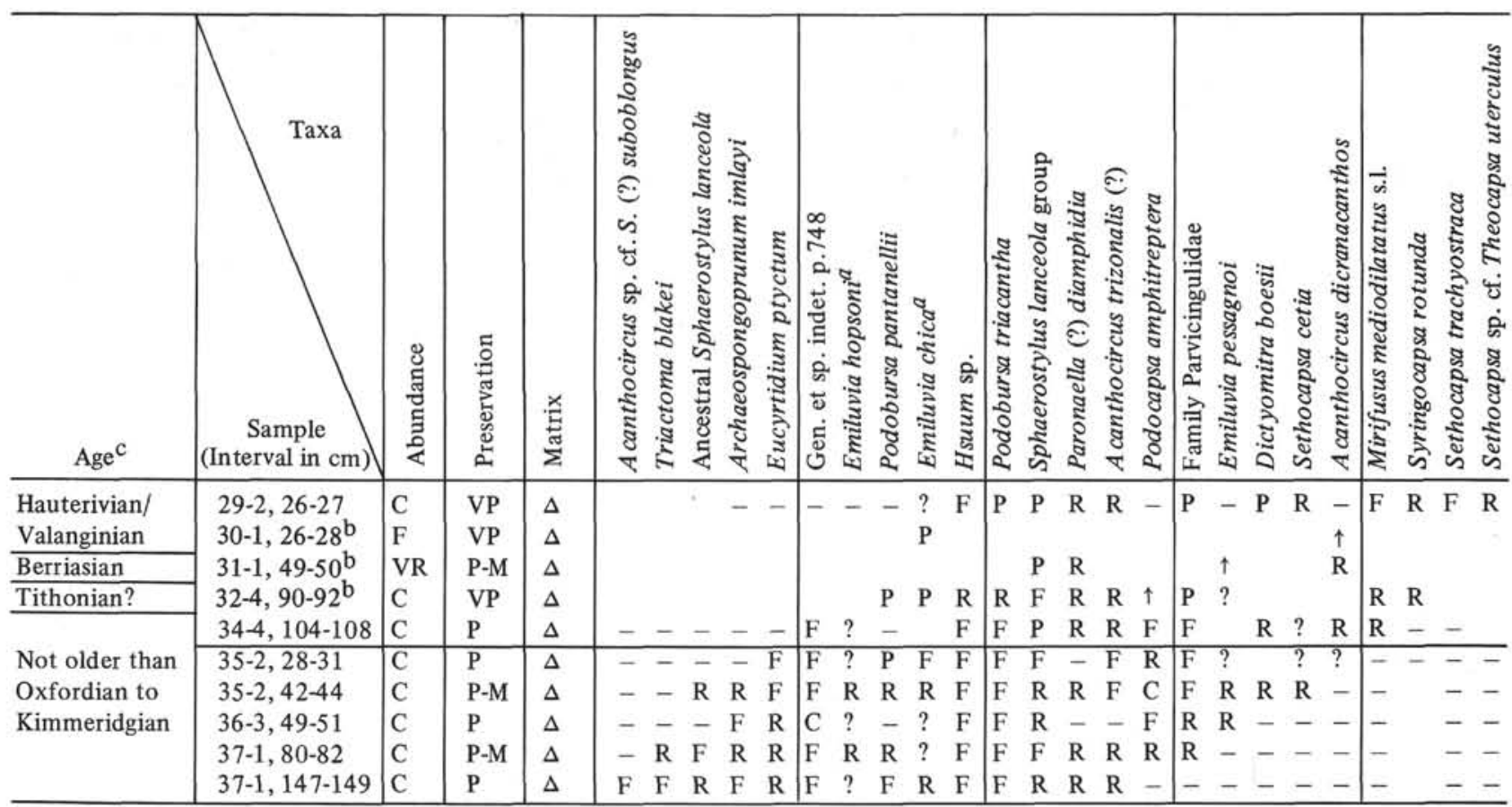

Footnotes and symbols are defined under the paragraph "Presentation of Results".

In the taxonomic section families are arranged alphabetically under the two major divisions of Spumellaria and Nassellaria and species are arranged alphabetically within each family. Type species designations which differ from those previously published are quoted from Foreman and Riedel, in press.

Five plates illustrate the Mesozoic Radiolaria. Plate 1 and Plate 2, Figures 1-8, Neocomian/Late Jurassic; and Plate 2, Figures 9-21, and Plates 3-5, Late Cretaceous.

\section{ZONATION}

For the Neocomian/Late Jurassic radiolarian bearing sequence of Cores 29-37 of Hole 367 only the broad zones of Riedel and Sanfilippo (1974) and Foreman (1975) could be applied. The more detailed zones of Pessagno (in press a, b) based on material from California are not applicable here. This is in part due to the poor preservation of this material.

For the Maestrichtian/late Campanian sequence of Hole 369A the zonation presented by Foreman (in press) is used. The whole sequence falls into the Amphipyndax tylotus Zone. The definition is repeated here. "The base is defined as the first evolutionary appearance of Amphipyndax tylotus. It includes near its base the first appearance of Lithomelissa hoplites and Lophophaena (?) polycyrtis. Also included are the last appearances of Clathropyrgus titthium and Afens liriodes. The top is defined as the Maestrichtian/Danian boundary recognized by the last occurrence of many of the species described from the California Maestrichtian (Foreman, 1968) which are recognized here, among them Lophophaena (?) polycyrtis, Theocampe bassilis, and Theocapsomma teren."

\section{PHYLOGENY}

Two new lineages have been determined.

1) Amphipyndax enesseffi- $A$. tylotus. This lineage consists of two species only. The origin of $A$. enesseff $i$ is obscure, but it probably arose from $A$. stocki. The lineage ends with $A$. tylotus.

2) Acidnomelos proapteron-A. apteron. This lineage also consists of two species only. Although no. connecting forms were observed, it appears quite obvious that $A$. apteron arose from $A$. proapteron by the loss of the ridges on the throax. The lineage ends with A. apteron.

\section{RADIOLARIA FROM EACH SITE}

\section{Hole 367 with Table 1}

Mesozoic Radiolaria in the nonsilicified sediments examined from Cores 15 through 28 are either absent or altered to pyrite. Pyritized Radiolaria were found as follows: $25, \mathrm{CC}$ (VR, VP); 26, CC (F, M); 27-3, 80-82 $\mathrm{cm}(\mathrm{R}, \mathrm{P}) ; 28-2,48-45 \mathrm{~cm}$ (R, M).

The following porcellanite and soft sediment samples from Cores 28 through 37 were examined: $\Delta-28-2$, $112-$ $113 \mathrm{~cm}$ (VR, M); $\Delta-28-2,143-145 \mathrm{~cm}$ (R, P); $\Delta-29-1,89$ $90 \mathrm{~cm}$ (VR, VP); $\Delta-29-2,26-27 \mathrm{~cm}$ (C, VP); 30-1, 12-14 $\mathrm{cm}$ (R, M pyretized); $\Delta-30-1,26-28 \mathrm{~cm}$ (F, VP and VR, G); $\Delta-31-1,49-50 \mathrm{~cm}$ (VR, P-M); $\Delta-31-1,148-150 \mathrm{~cm}$ (VR, G; and P); 31, CC (R, P and VR, G); 32-2, 12-14 $\mathrm{cm}(\mathrm{R}, \mathrm{P}$ partly pyretized) $\Delta-32-4,90-92 \mathrm{~cm}(\mathrm{C}, \mathrm{VP})$; $32-4,134-136 \mathrm{~cm} \mathrm{(-);32-5,} \mathrm{45-47} \mathrm{cm} \mathrm{(-);} \mathrm{32,} \mathrm{CC} \mathrm{light}$ grayish red ls. (F, VP) and dark reddish brown ls. (VR, VP); 33-2, 70-72 cm (-); 33-3, 105-107 cm (-); $\Delta-33-3$, $148-150 \mathrm{~cm}(-) ; 34-1.103-105 \mathrm{~cm}(\mathrm{VR}, \mathrm{M}) ; \Delta-34-4,104-$ 
TABLE 2

Occurrence and Abundance of Campanian/Maestrichtian Radiolaria of Hole 369A

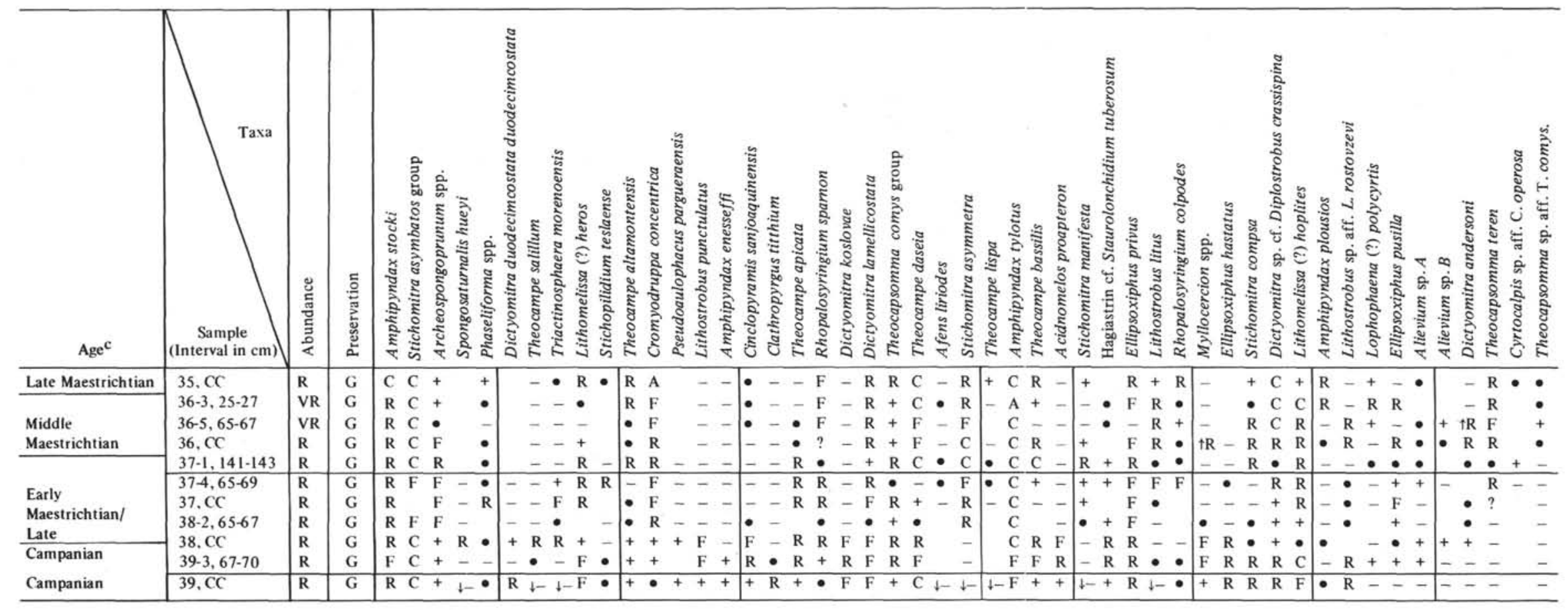

Note: Footnotes and symbols are defined under the paragraph "Presentation of Results." 
$108 \mathrm{~cm}(\mathrm{C}, \mathrm{P}) ; \Delta-35-2,28-31 \mathrm{~cm}(\mathrm{C}, \mathrm{P}$, and VR, M); $35-$ 2, $42-44 \mathrm{~cm}$ (C, P-M); 36-2, 20-22 cm (VR, P); $\Delta-36-3$, 49-51 cm (C, P); 37-1, 32-34 cm (VR, VP); $\Delta-37-1,34-37$ $\mathrm{cm}(\mathrm{F}, \mathrm{P}) ; \Delta-37-1,80-82 \mathrm{~cm}(\mathrm{C}, \mathrm{P}-\mathrm{M}) ; \Delta-37-1,147-149$ $\mathrm{cm}(\mathrm{C}, \mathrm{P})$; 37, CC (VR, VP).

The pyritized Radiolaria were generally too poor to attempt any age assignments except for 26, CC which on the basis of the presence of Lithocampe elegantissima and the general aspect of the fauna might be considered Albian/Aptian and 28-2, 44-45 cm which on the basis of the presence of a member of the Sphaerostylus lanceola group and the general aspect of the fauna might be considered Neocomian. Siliceous Radiolaria from Cores 29-32 are too poor, or too sparse to indicate anything but a broad Neocomian-Late Jurassic age. An exception is Sample 367-29-2, 26-27 cm which containing Sethocapsa cetia and $S$. trachyostraca is considered to be low in the Sethocapsa trachyostraca Zone. Samples from Cores 34-37 contained more abundant, slightly better preserved Radiolaria, but because Radiolaria in the Late Jurassic are not well enough known, the age assignments based on foraminiferal and nannofossil data are used on the occurrence table.

\section{Hole 368}

In the Paleogene where the soft sediments were barren, porcellanite samples yielded common, poor to moderately well preserved Radiolaria. In the Cretaceous sequence only Core 55 contained a layer of porcellanite. That sample, $55-2,8-10 \mathrm{~cm}$, yielded common, poorly preserved Radiolaria, CampanianConiacian (probably Campanian in age.) With the shipboard scientists noting only very rare, poor Radiolaria from this sequence, only two soft sediment samples near the bottom of the hole were examined, 60$1,139-141 \mathrm{~cm}$, and $62-3,1-3 \mathrm{~cm}$; both were barren.

\section{Hole 369A With Table 2}

Late Cretaceous Radiolaria were found in the unconsolidated sediments of Hole 369A from 35, CC to $39, \mathrm{CC}$. They are rare to very rare, with good preservation in all 27 samples examined except $37-1,95-97 \mathrm{~cm}$ (VR, M) and 39-3, 62-64 cm (R, M). Two samples of porcellanite yielded Radiolaria as follows: $39-2,102-$ $104 \mathrm{~cm}$ (VR, P) and 39-3, 21-23 cm (VR, G). No Radiolaria were found in $40-2,45-47 \mathrm{~cm}$, and none were reported by the shipboard paleontologists in the remaining Cores 41 through 47.

This Maestrichtian-Campanian radiolarian sequence is assigned according to foraminiferal and nannofossil data as follows: Sample 35, CC, late Maestrichtian; Core 36, middle Maestrichtian; Cores 37 and 38, early Maestrichtian-late Campanian and Core 39, Campanian.

Some members of the late Maestrichtian fauna described from California are well represented in Samples 36-3, 25-27 through 37-1, 141-143, and 38, CC through 39-1, 75-77. Samples 35 , CC through 36-2, 6567 ; 37-2, 85-87 through $38-5,55-57$; and 39-2, 75-77 through $39, \mathrm{CC}$, however, show a distinct boreal influence with many fine spongy discoidal forms similar to those described by Lipman (1952) from the Russian plateau and (1960) from western Siberia (Plate 2, Figures 18-21). The presence of the boreal fauna is most marked in Samples 35, CC and 37-6, 45-47 through 38$2,65-67$. Because of this, it is not yet possible to confidently determine the base or the top of a species range in this sequence when that top or base would fall in the part of the column where its absence might be due to temperature changes. The sparseness of the fauna also contributes to uncertainty. However, because preservation was good and individual species could easily be recognized, it was possible to extend upward the ranges of a number of taxa that had heretofore only been reported in strata as young as the Campanian and downward, species that had only been reported from the late Maestrichtian.

\section{SYSTEMATIC SECTION}

Constraints of time for this Initial Report do not allow a detailed investigation into the family relationships of all the species presented here. Therefore many species have been assigned to families based on the broad definitions of Riedel (1967a, b) or left unassigned as with the group of nassellarians with large cephali (Radiolaria of uncertain affinities.)

\section{SPUMELLARIA Ehrenberg, 1875}

Family ACTINOMMIDAE Haeckel, 1862; emend. Riedel, 1967b

\section{Genus CROMYODRUPPA Haeckel}

Cromyodruppa Haeckel, 1887, p. 317. Type species (subsequent designation by Campbell, 1954, p. D70) Cromyodruppa cepa Haeckel, 1887 , p. 317.

Remarks: It is not likely that the species described by Lipman (1952) or those described by Kozlova and Gorbovetz (1966) are related to the type species $C$. cepa of this genus. The assignment remains unchanged as a convenience until a more appropriate generic assignment can be made.

\section{Cromyodruppa (?) concentrica Lipman}

(Plate 2, Figure 18)

Cromyodruppa concentrica Lipman in Kozlova and Gorbovetz, 1966, p. 62 , pl. 1 , fig. $1-4$.

\section{Genus ELLIPSOXIPHUS Dunikowski}

Ellipsoxiphus Dunikowski, 1882, p. 185. Type species (subsequent designation by Campbell, 1954, p. D69) Ellipsoxiphus parvoforaminosus (Dunikowski) $=$ Xiphosphaera parvoforaminosa Dunikowski, 1882, p. 186, pl. 5, fig. 51 .

Remarks: It is not likely that the species described below are closely related to the type species of Ellipsoxiphus. However, the name is used here as a temporary expedient until the relationship of these Late Cretaceous forms to early Cenozoic forms is more clearly understood.

\section{Ellipsoxiphus hastatus (Campbell)}

(Plate 2, Figure 13)

Sphaerostylus sphaerostylantha hastatus Campbell in Campbell and Clark, 1944, p. 5, pl. 1, fig. 1, 6.

Description: This form consists of two shells, an outer spherical or almost spherical shell with two opposing, unequal three-bladed polar spines, and a small spherical inner shell. When the outer shell is very slightly ellipsoidal the long axis is commonly in the plane perpendicular to the polar spines (transverse). Pores are fairly uniform in size, circular to subcircular, set in angular frames which in almost all cases roughen the surface by forming blunt nodes at their junctions.

Measurements (based on 13 specimens from Hole 369A, Cores 3739.) Transverse width of outer shell $95-125 \mu \mathrm{m}$, vertical width $95-110$ $\mu \mathrm{m}$; transverse width of one inner shell $22 \mu \mathrm{m}$; length of spines $40-185$ $\mu \mathrm{m}$. 
Remarks: Of the specimens examined in this material and the one specimen observed in a small sample of topotypic material, only one, in Sample 369A-39, CC, has a small inner shell. No radial beams were seen in the specimens which lacked a shell. Specimens from the older samples tend to be less robust with weaker polar spines.

\section{Ellipsoxiphus privus Foreman, new species}

(Plate 2, Figures 14-16)

Stylatractus (?) sp. Kozlova in Petrushevskaya and Kozlova, 1972, pl. 4 , fig. 3, 4

Ellipsoxiphus sp. A Foreman, in press, fig. 6, p. 11, pl. 1, fig. 4. Ellipsoxiphus sp. B Foreman, in press, fig. 6, p. 11, pl. 1, fig. 5.

Description: The outer shell is ellipsoidal with subcircular pores, varying considerably in size. The surface may be fairly smooth or roughened by raised areas at the junction of the pore frames. These raised areas sometimes develop as short by-spines. Three inner shells (sometimes two?) are ellipsoidal to circular. The largest of the inner shells has approximately equal, rounded pores in angular pore frames. They are connected by the stout, bladed primary radial beam extensions of the two opposing polar spines and a few secondary radial beams. The polar spines are unequal in length and generally three-bladed partly or throughout their length. Rare specimens with almost entirely smooth spines are also included.

Measurements (based on 15 specimens from Hole 369A, Cores 35, 37-39): length of ellipsoid 95-150 $\mu \mathrm{m}$; width of ellipsoid 70-115 $\mu \mathrm{m}$.

Remarks: This species is relatively common throughout the Maestrichtian-Campanian sequence of Hole 369A. In Foreman (in press) it was considered that this form could usefully be divided into two species, $E$. sp. A and $E$. sp. B on the basis of size. Further investigation, however, shows this distinction to be artificial and difficult to apply; thus all forms are here considered to belong to one species regardless of size. Larger specimens are more commonly present in Cores 38 and 39.

In comparative material from CAS loc. 39545 (Foreman, 1968) the outer shell is variably developed, and in rare cases missing entirely. When it is missing, a slight change in contour on the two main spines may be noted at the approximate point where the outer shell, if present, would intersect the spines. In this exceptionally welldeveloped material the spine tips sometimes are developed with one main point, and two very slightly developed minor points.

Etymology: The specific name is from the Latin adjective privus, simple.

\section{Ellipsoxiphus pusilla (Campbell)}

(Plate 2, Figures 9, 10, 17)

Stylosphaera (Stylosphaerella) pusilla Campbell in Campbell and Clark, 1944, p. 5, pl. 1, fig. 2, 4, 5.

Druppatractona sp. A in Foreman, in press, pl. 1, fig. 3.

Description: This form consists of two shells and two opposed polar spines of unequal length. The outer shell may be spherical or ellipsoidal with the long axis (vertical width) in the plane of the polar spines. Subcircular pores are fairly uniform in size on individual specimens but vary considerably in size among them, from moderate as on the illustration (Plate 2, Figure 9) to very small (Plate 2, Figure 17). They are generally set in angular pore frames. When these are well developed, the surface is roughened by blunt raised areas, or sometimes sharp thorns at the junction of the frames. When they are missing or only weakly developed, the shell is smooth. The inner shell is subspherical in form with an uneven surface due to the pore frames forming an angular bulged surface at the points where the slender secondary radial beams, which connect the inner shell to the outer shell, protrude. Although they were searched for, no heavier primary radial beams extending directly from the inner shell to the polar spines of the outer shell could be distinguished. The polar spines may be three-bladed or smooth and are sometimes slightly tipped so that they do not extend in an exact straight line with each other.

Measurements (based on 25 specimens from UCMP loc. A2615, CAS loc. 39545, Moreno Gulch [Foreman, 1968] and Hole 369A, Cores 36-38.) Transverse width of outer shell $60-90 \mu \mathrm{m}$ (majority $70-$ $80 \mu \mathrm{m}$ ), vertical width of outer shell $70-100 \mu \mathrm{m}$, transverse width of inner shell $20-30 \mu \mathrm{m}$; length of short polar spine $50-70 \mu \mathrm{m}$, of long polar spine $75-110 \mu \mathrm{m}$.

Remarks: This species is described more broadly than by Campbell and includes forms with smooth and thorny shells, and spines, which may be bladed or smooth.

\section{Genus SPHAEROSTYLUS Haeckel}

Sphaerostylus Haeckel, 1881, p. 451; Foreman, 1973, p. 258. Pantanellium Pessagno, in press.

Remarks: We continue to use the generic name Sphaerostylus Haeckel because the type species (by subsequent monotypy) Sphaerostylus zittelii Rust, from the coproliths of Ilsede (Upper Lias or Lower Dogger), although poorly illustrated and only briefly described, clearly has the features, i.e., two opposite bladed polar spines, and two shells, the outer with exceptionally large pores, which are present in the species assigned here. Thus Pantanellium Pessagno, type species $P$. riedeli Pessagno, is considered a subjective synonym.

\section{Sphaerostylus lanceola (Parona) group}

(Plate 1, Figure 10)

Sphaerostylus lanceola (Parona) group in Foreman, 1973, p. 258, pl. 1, fig. 7-11; 1975, p. 609, pl. 2E, fig. 2-6.

Pantanellium fischeri (Pessagno), in press.

Pantanellium riedeli Pessagno, in press.

Remarks: The variable forms in the synonymy above continue to be grouped together, because of the diffuculity of making fine distinctions on poorly preserved specimens. An exception is the ancestral form of Sphaerostylus lanceola illustrated by Riedel and Sanfilippo (1974) whose large, broad, robust spines and relatively small elliptical shell are easily recognized even in poor material. The name $S$. lanceola (Parona) continues to be used because that form has priority and its illustration and clear description agree very well with some of the forms that have been observed.

In well-preserved material the distinctions made by Pessagno, in describing Pantanellium fischeri, can be applied more easily.

\section{Ancestral Sphaerostylus lanceola \\ (Plate 1, Figure 11)}

Form ancestral to Sphaerostylus lanceola (Parona) Riedel and Sanfilippo, 1974, p. 780 , pl. 1, fig. 4, 5; pl. 12, fig. 1.

Remarks: See "Remarks" under Sphaerostylus lanceola (Parona) group.

\section{Genus TRIACTOMA Rüst}

Triactoma Rust, 1885, p. 289; Loeblich and Tappan, 1961, p. 244; Foreman, 1973, p. 259.

Remarks: The type species of Triactoma is $T$. tithonianum Rust, 1885 , p. 289 , pl. 28 , fig. 5 , described as a spherical form but observed as a slightly flattened sphere, elliptical in cross-section. Therefore it cannot, as suggested by Pessagno (in press), be considered a subjective synonym of Tripocyclia Haeckel, 1881, whose type species, by subsequent monotypy, $T$. trigonum Rust, 1885, p. 293 , pl. 3 , fig. 3 is described and illustrated as a triangular discoidal form.

\section{Triactoma blakei (Pessagno)}

(Plate 1, Figure 15)

Tripocyclia blakei Pessagno, in press, pl. 6, fig. 15, 16.

[?] Triactoma pachyacantha R List, 1885, p. 289, pl. 28, fig. 6 .

Remarks: $T$. pachyacantha Rust is only doubtfully included in the synonomy because its illustration shows one odd spine. The other described features, i.e., shape, diameter, and length of spines, agree very well.

\section{Triactoma jonesi (Pessagno)}

(Plate 1, Figures 13, 14)

Tripocyclia jonesi Pessagno, in press, pl. 7, fig. 1-5.

Remarks: Most of the forms which might be identified as belonging to this species had spines broken off. When the spines are incomplete it is not possible to distinguish confidently this form from $T$. tithonianum which has a similarly shaped shell, in the same size range and differs only in having spines terminating in simple points. Because of this uncertainty, neither $T$. jonesi or $T$. tithonianum have been tabulated. The few forms with one complete spine that could be identified as $T$. jonesi had somewhat larger diameters $(175-250 \mu \mathrm{m})$ than those measured by Pessagno.

\section{Triactoma tithonianum Rüst}

Triactoma tithonianum Rüst, 1885 , p. 289, pl. 28, fig. 5; Foreman, 1973 , p. 260 , pl. 2 , fig. $1 ; 1975$, p. 610 , pl. 3 , fig. 13.

Remarks: See "Remarks" under $T$. jonesi. 
Subfamily SATURNALINAE Deflandre, 1953

Genus ACANTHOCIRCUS Squinabol

Acanthocircus Squinabol, 1903, p. 124; Foreman. 1973, p. 260.

\section{Acanthocircus dicranacanthos (Squinabol)}

(Plate 1, Figure 7)

Saturnalis dicranacanthos Squinabol, 1914, p. 289, fig. 1; pl. 22, fig. $4-7$; pl. 23 , fig. 8 .

Acanthocircus dicranacanthos (Squinabol) in Foreman, 1975, p. 610, pl. 20, fig. 5, 6 .

\section{Acanthocircus trizonalis (Ruist) (?) emend.}

$$
\text { (Plate 1, Figure 9) }
$$

Acanthocircus trizonalis (Rüst) in Foreman, 1973, p. 610, pl. 20, fig. 1-4.

Remarks: This species is present in the oldest sample bearing radiolarians and thus arose at the very latest in the Kimmeridgian, perhaps eariler.

\section{Acanthocircus sp. cf. Spongosaturnalis (?) suboblongus Yao} (Plate 1, Figure 8)

cf. Spongosaturnalis (?) suboblongus Yao, 1972, p. 29, pl. 3, fig. 1-6; pl. 10, fig. 3a-c.

Remarks: The fragments of an elliptical ring bearing two distinctive ridged spines are very like those described and illustrated for $S$. (?) suboblongus.

\section{Genus SPONGOSATURNALIS Campbell}

Spongosaturnalis Campbell in Foreman, 1973, p. 261.

\section{Spongosaturnalis hueyi (Pessagno} (Plate 3, Figure 8)

Spongosaturninus hueyi Pessagno, in press, pl. 12, fig. 1. Spongosaturnalis hueyi (Pessagno) in Foreman, 1975, pl. 1A, fig. 6; pl. 4 , fig. 10 .

\section{Family PHACODISCIDAE Haeckel, 1881 (?)}

Genus EMILUVIA Foreman, emend.

Emiluvia Foreman, 1973, p. 262; emend. 1975, p. 612.

\section{Emiluvia chica Foreman s. I.}

(Plate 1, Figure 4)

Emiluvia chica Foreman, 1973, p. 262, pl. 8, fig. 7; 1975, p. 612, pl. 5, fig. 12, 13; Pessagno, in press, pl. 4, fig. 11-13.

Remarks: The forms originally described by Foreman s.s. had simple spine tips, and distinctly larger nodes at the base of each spine. Pessagno (in press) has since included forms with spines that end with a slender rod-like tip and with nodes at the base of each spine which do not differ in size from those on the rest of the shell. In poor material it is not possible to confidently distinguish these two forms and they are here treated as $E$. chica s.l. In well-preserved material it will be usefu! to distinguish these two forms as $E$. chica Foreman s.s. differs in the extent of its range (younger) than E. chica in Pessagno (in press). A third related form with large nodes over all and spine tips which bifurcate, Emiluvia hopsoni Pessagno (in press) also cannot be distinguished in poor material or when the distinctive spine tips are broken off.

Emiluvia chica s.l. and E. hopsoni are tabulated. Question marks in the tabulations indicate uncertainty in identifying $E$. chica s.l. and $E$. hopsoni when they are known to co-occur and specimens are broken.

\section{Emiluvia hopsoni Pessagno} (Plate 1, Figure 3)

Emiluvia hopsoni Pessagno, in press, pl. 4, fig. 14-16; pl. 5, fig. 1-7. Remarks: See "Remarks" under E. chica.

\section{Emiluvia pessagnoi Foreman}

(Plate 1, Figures 1, 2)

Emiluvia pessagnoi Foreman, 1973, p. 262, pl. 8, fig. 6, 1975, p. 612. [?] Emiluvia pessagnoi Pessagno, in press, pl. 5, fig. 8.

Remarks: The form figured by Pessagno is only doubtfully included because no nodes can be distinguished on its surface.

\section{Family PHASELIFORMIDAE Pessagno, 1972}

\section{Genus PHASELIFORMA Pessagno}

Phaseliforma Pessagno, 1972a, p. 274.

\section{Phaseliforma spp. \\ (Plate 3, Figure 3)}

Remarks: A variety of forms belonging to this genus are present throughout the Maestrichtian-Campanian sequence of Hole 369A. The illustrated form differs from any of the species described by Pessagno in its shape.

\section{Family PSEUDOAULOPHACIDAE Riedel, 1967a}

Remarks: Most of the members of this family observed here, do not readily fit into the evolutionary scheme proposed by Pessagno (1972b). Most of the specimens illustrated may therefore represent entirely new species and lineages. They are, in this material, too rare to attempt a complete description, only some dimensions, descriptive notes, and an illustration are given.

\section{Genus ALIEVIUM Pessagno emend.}

Alievium Pessagno, 1972b, emend. Foreman, 1973, p. 262.

Alievium sp. A.

(Plate 3, Figures 4, 6)

Pseudoaulophacus gallowayi (White) (?) in Kozlova and Petrushevskaya, 1972, p. 527, pl. 6, fig. 1 .

Remarks: This species differs from Alievium superbun in the smaller size of its shell and the larger size of its spines. The shape varies from triangular to almost rectangular.

Alievium sp. B

(Plate 3, Figures 1, 2)

Remarks: This species differs from $A$. murpheyi Pessagno in having short, basally bladed spines, with a much larger meshwork. Measurements of one specimen are as follows: width of shell $210 \mu \mathrm{m}$, length of spines $45 \mu \mathrm{m}, 50 \mu \mathrm{m}$. It is extremely rare and has been observed only in Samples 36-5, 65-67 cm; 36, CC; and 38, CC from the Late Cretaceous sequence of Hole 369A.

\section{Genus PSEUDOAULOPHACUS Pessagno}

Pseudoaulophacus Pessagno, 1963, p. 200.

\section{Pseudoaulophacus pargueraensis Pessagno \\ (Plate 3, Figure 9)}

Pseudoaulophacus pargueraensis Pessagno, 1963, p. 204, pl. 2, fig. 4, 7 ; pl. 6, fig. 4,5 .

\section{Pseudoaulophacus sp. aff. P. delvallensis}

(Plate 3, Figure 5)

Pseudoaulophacus delvallensis Pessagno, in press, pl. 9, fig. 9, 10.

Remarks: The form illustrated here was observed too late to be recorded on the occurrence chart. It appears to be related to $P$. delvallensis, but differs from that form in having much sturdier, and longer, three-bladed spines.

Family SPONGODISCIDAE Haeckel, 1862; emend. Riedel, 1967b

$$
\text { Genus PARONAELla Pessagno }
$$

Paronaella Pessagno, 1971, p. 46; Foreman, 1973, p. 262.

\section{Paronaella (?) diamphidia Foreman \\ (Plate 1, Figures 5, 6)}

Paronaella (?) diamphidia Foreman, 1973, p. 262, pl. 8, fig. 3, 4.

Remarks: The early specimens observed here either lack or have a very much reduced, weak, oblique, third arm.

\section{Genus TRIACTINOSPHAERA Dunikowski}

Triactinosphaera Dunikowski, 1882, p. 192. Type species (by monotypy) Triactinosphaera zitteli Dunikowski, 1882, p. 192 , pl. 6 , fig. $69,69 a, 70,70 a$. 
Triactinosphaera morenoensis (Campbell) (Plate 2, Figure 20)

Spongotripus (Spongotripodiscus) morenoensis Campbell in Campbell and Clark, 1944, p. 19, pl. 5, fig. 1.

Rhopalastrum tumidum Lipman, 1952, p. 37, pl. 2, fig. 13

Triactinosphaera sp. Foreman, in press, pl. 1, fig. 13.

\section{Hagiastrin cf. Staurolonchidium tuberosum Rüst} (Plate 3, Figure 7)

Staurolonchidium tuberosum Rùst, 1898, p. 10, pl. 2, fig. 7.

Hagiastrin cf. Staurolonchidium tuberosum Rust in Riedel and Sanfilippo, 1974, p. 779, pl. 14, fig. 5-8.

Remarks: Only broken fragments of this distinctive form have been observed.

\section{Family SPONGOURIDAE Haeckel, 1862}

Genus ARCHAEOSPONGOPRUNUM Pessagno

Archaeospongoprumum Pessagno, 1973, p. 57.

\section{Archaeospongoprunum imlayi Pessagno}

(Plate 1, Figure 12)

Archaeospongoprunum imlayi Pessagno, in press, pl. 3, fig. 1, 2.

\section{Archaeospongoprunum spp.}

(Plate 2, Figures 11, 12)

Remarks: Archaeospongoprumum hueyi is present in the Late Cretaceous sequence of Hole 369A. Other forms with four-bladed spines, one twisted, are also present. These cannot be identified confidently as $A$. cortinaensis because of their greater size, and appearance in strata outside the range given by Pessagno for that species. Specimens of Archaeospongoprunum are common, but they frequently have one or both spines broken thus making them difficult to identify and tabulate individually. They all appear as Archaeospongoprumum spp. on the occurrence table.

Nassellaria Ehrenberg, 1875

\section{Family AMPHIPYNDACIDAE Riedel, 1967a}

\section{Genus AMPHIPYNDAX Foreman}

Amphipyndax, Foreman, 1966, p. 355.

\section{Amphipyndax enesseffi Foreman}

(Plate 4, Figure 3)

Amphipyndax enesseffi Foreman, 1966, p. 356, fig. 10, 11.

Remarks: $A$. enesseffi may be distinguished from $A$. tylotus as described under the "Remarks" for that species.

\section{Amphipyndax plousios Foreman}

(Plate 4, Figure 5)

Amphipyndax plousios Foreman, 1968, p. 79, pl. 8, fig. 11.

\section{Amphipyndax stocki (Campbell)}

(Plate 4, Figure 4)

Amphipyndax stocki (Campbell) in Foreman, 1968, p. 78, pl. 8, fig. $12 \mathrm{a}-\mathrm{c}$.

Remarks: As noted in 1968, forms included vary considerably in appearance because of the variation in pore size among individual specimens. Although it still does not seem feasible to divide this species on the basis of pore size, it seems useful to note that in the Late Cretaceous sequence of Hole $369 \mathrm{~A}$, specimens with large pores are more common in the Maestrichtian and early Maestrichtian-late Campanian samples than in the Campanian samples.

\section{Amphipyndax tylotus Foreman new species} (Plate 4, Figures 1, 2)

Amphipyndax tylotus Foreman, in press, pl. 1, fig. 1

Amphypyndax sp. aff. A. enessefi Foreman in Petrushevskaya and Kozlova, 1972, pl. 8, fig. 14.

Amphipyndax enessefi Foreman in Petrushevskaya and Kozlova, 1972 , pl. 8 , fig. 15 .

Description: Shell acutely conical proximally, tending to become cylindrical distally, with the most distal segments narrowing slightly.
Although the last segment is always broken, there is some evidence to suggest it may constrict to form a wide terminal tube. The poreless cephalis is internally as for other members of this genus and externally roughened by small shallow nodes. The remaining segments all have numerous, small, rounded, subcircular pores, generally irregularly arranged, sometimes with a tendency to transverse alignment. Random ridges on the intervening pore bars between groups of pores form nodes when they coalesce. These irregularly arranged nodes are well developed on all the post-cephalic segments except the thorax where they are rather shallow and the one or two constricting terminal segments which are less robust.

Measurements (based on 10 specimens from Hole 369A, Cores 35 , 36, and 38; and Hole 13A, Core 2). Greatest length of specimen with $11+$ segments $370 \mu \mathrm{m}$; length of seven segments $185-220 \mu \mathrm{m}$; width of seventh segment $85-110 \mu \mathrm{m}$.

Remarks: This species is distinguished from Amphipyndax enesseffi, which it resembles, by having segments with nodes over all, rather than only on the segment dividing strictures. The two species co-occur towards the end of the range of $A$. enesseffi, and $A$. tylotus may be considered a descendant of that species.

Etymology: The specific name is from the Greek adjective tylotos, knobby.

\section{Family ARTOSTROBIIDAE Riedel 1967a}

Genus THEOCAMPE Haeckel, emend.

Theocampe Haeckel, 1887; emend. Burma, 1959, p. 328.

\section{Theocampe altamontensis (Campbell)}

(Plate 5, Figure 27)

Tricolocampe (Tricolocamptra) altamontensis Campbell in Campbell and Clark, 1944, p. 33, pl. 7, fig. 24, 26.

Theocampe altamontensis (Campbell) in Foreman, 1968, p. 53, pl. 6, fig. $14 \mathrm{a}, \mathrm{b}$.

Theocampe apicata Foreman

(Plate 5, Figures 21, 22, 28)

Theocampe apicata Foreman, 1971, p. 1679, pl. 4, fig. C.

[?] Dictyomitra ehrenbergi Zittel, 1876, p. 82, pl. 2, fig. 5.

Theocampe sp. P. Kozlova in Petrusheveskaya and Kozlova, p. 537, pl. 7, fig. 1 .

Remarks: Some of the late forms observed in this material are not as distinctly flattened, or triangular in shape when observed perpendicular to the lateral plane as the early forms described from DSDP, Hole 61 (Foreman, 1971). They are, however, all more expanded in that plane than in the sagittal plane. Measurements for the abdomen of one of these narrower forms are: greatest width in lateral plane $70 \mu \mathrm{m}$ in sagittal plane $55 \mu \mathrm{m}$. Narrow forms are distinguished from $T$. lispa and $T$. ascalia by being expanded in the lateral plane. $T$. apicata also differs from $T$. lispa in having a shorter thorax and a more constricted even aperture, and from $T$. ascalia in having a longer abdomen. (Compare T. lispa Plate 5, Figure 29, and T. apicata Plate 5, Figure 28.)

Dictyomitra ehrenbergi Zittel is questionably synonymized with $T$. apicata because of its short thorax and shape, which is similar to the late forms of $T$. apicata observed here. It might equally well be synonymized with $T$. ascalia which also has a short thorax and a relatively wider aperture as does $D$. ehrenbergi. Measurements of $D$. ehrenbergi fall intermediately between $T$. apicata and $T$. ascalia. It will be necessary to examine topotypic material before this question can be resolved.

\section{Theocampe bassilis Foreman}

(Plate 5, Figure 25)

Theocampe bassilis Foreman, 1968, p. 50, pl. 6, fig. 10.

Theocampe ? bassilis Foreman in Petrushevskaya and Kozlova, 1972 , p. 537 , pl. 7 , fig. 7 .

Remarks: See "Remarks" under $T$. daseia for distinguishing features.

\section{Theocampe daseia Foreman}

(Plate 5, Figure 26)

Theocampe daseia Foreman, 1968, p. 48, pl. 6, fig. 9a, b.

Theocampe? sp. aff. T. daseia Foreman in Petrushevskaya and Kozlova, 1972, p. 537, pl. 7, fig. 8-10. 
Remarks: $T$. daseia and $T$. bassilis may be distinguished from each other by the larger thorax and smaller abdominal pores of $T$. daseia. The presence of a distinct sharp apical horn for $T$. daseia mentioned by Foreman (1968) as a distinguishing feature, is not applicable to the material from the Maestrichtian-Campanian sequence of Hole $369 \mathrm{~A}$.

\section{Theocampe lispa Foreman \\ (Plate 5, Figure 29)}

Theocampe lispa Foreman, 1968, p. 49, pl. 6, fig. 11.

Remarks: This form, although extremely rare here, is illustrated in order to distinguish it from T. apicata. See "Remarks" under $T$. apicata.

\section{Theocampe salillum}

Theocampe salillum Foreman, 1971, p. 1678, pl. 3, fig. 4.

\section{Family PARVICINGULIDAE Pessagno, in press}

Remarks: Although the material from Hole 367 was too poor to identify many individual species, members of the family could be easily recognized by their distinctive closely spaced rings of ridges. Mirifusus boesii is apparently the last representative of the family.

\section{Genus MIRIFUSUS Pessagno}

Mirifusus Pessagno, in press. Type species (by original designation) Mirifusus guadalupensis Pessagno, in press (b), pl. 10, fig. 9, 10.

\section{Mirifusus boesii (Parona)}

(Plate 2, Figure 6)

Dictyomitra boesii Parona, 1890, p. 170, pl. 6, fig. 9; Riedel and Sanfilippo, 1974, p. 778 , pl. 4, fig. 5, 6 .

\section{Mirifusus mediodilatata (Rüst) s.l.} (Plate 2, Figure 3)

Lithocampe mediodilatata Rüst, 1885 , p. 316 , pl. 40, fig. 9. Foreman, 1975, p. 616, pl. 2K, fig. 2; pl. 6, fig. 17 .

Mirifusus (?) mediodilatata (Rüst) in Pessagno, in press (b), pl. 11, fig. $1,2$.

Mirifusus baileyi Pessagno, in press (b), pl. 10, fig. 6-8; pl. 11, fig. 911.

Mirifusus guadalupensis Pessagno, in press (b), pl. 10, fig. 9-14.

Mirifusus sp. A Pessagno, in press (b), pl. 10, fig. 15, 16.

Gen. and sp. indet. Foreman, 1973, pl. 12, fig. 2.

Remarks: The delicate distinctions based on layers of the shell could not be distinguished in this material or in any of the other DSDP samples where this form has been observed. Frequently only fragments of a shell are found and no distinction on the basis of shape can be made. It therefore seems useful to be able to record this species in a much broader sense than that given by Pessagno. $M$. mediodilatata s.l. as defined here includes all forms with the distinctive two-row triangular to subtriangular pattern of pores, each two-row segment defined externally by a raised area made up of coalescing nodes. At the present time this surface pattern is known only from forms with a relatively slender proximal portion, and a greatly expanded central part, which on the better preserved specimens narrows to form a cylindrical distal part. Fragments of shell may be distinguished from the smaller more cylindrical species assigned to the genus Parvicingula by their size.

This form on the basis of its shape might equally well be assigned to the subfamily Syringocapsinae.

\section{Family THEOPERIDAE Haeckel, 1881; emend. Riedel, 1967b}

\section{Genus CINCLOPYRAMIS Haeckel}

Cinclopyramis Haeckel, 1879, p. 705. Type species (by monotypy) Cinclopyramis murrayana Haeckel, 1879, p. 705.

\section{Cinclopyramis sanjoaquinensis (Campbell)}

(Plate 5, Figures 15, 23)

Bathropyramis (Acropyramis) sanjoaquinensis Campbell in Campbell and Clark, 1944, p. 22, pl. 7, fig. 2

Bathropyramis sanjoaquinensis Campbell and Clark in Petrushevskaya and Kozlova, 1972, p. 551, pl. 7, fig. 20.

Bathropyramis sp. Riedel and Sanfilippo, 1974, p. 775, pl. 3, fig. 9, 11.

\section{Genus CLATHROPYRGUS Haeckel}

Clathropyrgus Haeckel, 1881, p. 435. No legal type species has been designated.

\section{Clathropyrgus titthium Riedel and Sanfilippo}

(Plate 5, Figure 19)

Clathropyrgus titthium Riedel and Sanfilippo, 1974, p. 775, pl. 3, fig. 12; pl. 12, fig. 10-12.

Remarks: This species is recorded only from Core 39 in Hole $369 \mathrm{~A}$, and thus its upper limit would seem to fall near the top of the Campanian. It has, however, been previously observed from CAS loc. 39545 (Foreman, 1968) early Maestrichtian-(?) late Campanian, and thus may range slightly higher.

\section{Genus CYRTOCALPIS Haecke}

Cyrtocalpis Haeckel, 1860, p. 835. Type species (subsequent designation by Campbell, 1954, p. D121) Cyrtocalpis amphora Haeckel, 1860 , p. $835 ; 1862$, pl. 5 , fig. 2.

Remarks: There is little likelihood that the Tertiary type species of Cyrtocalpis is related to $C$. operosa. The generic assignment remains unchanged as a matter of convenience.

\section{Cyrtocalpis sp. aff. operosa Tan Sin Hok}

(Plate 5, Figure 6)

Cyrtocalpis operosa Tan Sin Hok in Riedel and Sanfilippo, 1974, p. 778 , pl. 4 , fig. $1-3$; pl. 14, fig. 10

Remarks: The shell is very similar to that of Cyrtocalpis operosa Tan Sin Hok in Riedel and Sanfilippo, 1974, but differs from that form in having pores arranged in transverse rows.

\section{Genus DICTYOMITRA Zittel}

Dictyomitra Zittel, 1876, p. 77. Foreman, 1973, p. 263.

\section{Dictyomitra andersoni (Campbell)}

(Plate 4, Figure 6)

Dictyomitra andersoni (Campbell) in Foreman, 1968, p. 68, pl. 7 , fig. 6a-d.

Remarks: See "Remarks" under Dictyomitra sp. cf. Diplostrobus crassispina.

\section{Dictyomitra duodecimcostata duodecimcostata (Squinabol)}

(Plate 4, Figures 8, 9)

Lithostrobus duodecimcostata Squinabol, 1903, p. 138, pl. 10, fig. 21.

Dictyomitra duodecimcostata (Squinabol) in Foreman, 1975, p. 614 (partim), pl. 7, fig. 8 .

Dictyomitra torquata Foreman, 1973, pl. 15, fig. 9, 11

Remarks: As our knowledge of $D$. duodecimcostata has increased it seems useful to divide it into two subspecies, $D$. duodecimcostata duodecimcostata which is robust, may or may not have a first or second expanded segment which is differentiated from the remaining segments either by size or shape, but must have all the subsequent segments completely convexly expanded, except for one or two last cylindrical segments. Dictyomitra duodecimcostata torquata also may or may not have a first and/or second differentiated segment. It differs, however, in having all the subsequent segments proximally concave and only distally expanded. A second row of pores is present on the distal half of these distal segments. Some of the very latest forms of $D$. duodecimcostata duodecimcostata tend to have these distal segments evenly expanded (Plate 4, Figure 9). The more typical form is illustrated on Plate 4, Figure 8.

\section{Dictyomitra duodecimcostata torquata Foreman}

Dictyomitra torquata Foreman, 1971, p. 1676, pl. 3, fig. 4; 1973 , pl. 15, fig. 10; 1975, p. 614 (partim).

Remarks: Dictyomitra duodecimcostata torquata as a subspecies has a somewhat narrower definition than the original $D$. torquata Foreman (1971). See "Remarks" under D. duodecimcostata duodecimcostata.

\section{Dictyomitra koslovae Foreman}

(Plate 4, Figure 10)

Dictyomitra koslovae Foreman, 1975, p. 614, pl. 7, fig. 4. Dictyomitra sp. in Foreman, 1971, p. 1677, pl. 3, fig. 5; 1973, pl. 15, fig. 13-15. 
Dictyomitra lamellicostata Foreman

(Plate 4, Figures 13, 14)

Dictyomitra lamellicostata Foreman, 1968, p. 65, pl. 7, fig. 8a, b.

\section{Dictyomitra regina (Campbell)}

Dictyomitra regina (Campbell) in Foreman, 1968, p. 68, pl. 8, fig. 5a-c.

Remarks: Only one specimen of this species was observed in Sample 39, CC in the Maestrichtian-Campanian sequence of Hole 369 A.

\section{Dictyomitra sp. cf. Diplostrobus crassispina Squinabol} (Plate 4, Figure 7)

Dictyomitra cf. Diplostrobus crassispina Squinabol in Foreman, 1968, p. 67 , pl. 7 , fig. $7 \mathrm{a}$, b.

Remarks: There is a great variation in size in both Dictyomitra andersoni and $D$. sp. cf. Diplostrobus crassispina. They may be distinguished from one another by the following features: $D$. andersoni has segments which do not increase regularly in length. The longest segment of that form is usually a median one. It also has only moderately symmetrically inflated segments. D. sp. cf. Diplostrobus crassispina, on the other hand, has on the conical portion, which is the part which may be confused with $D$. andersoni, segments increasing regularly in length and individual segments which are more inflated on their proximal half.

\section{Genus EUCYRTIDIUM Ehrenberg}

Eucyrtidium Ehrenberg, 1847a, chart to p. 385. Type species (by subsequent designation) Frizzell and Middour, 1951, p. 33. Lithocampe acuminata Ehrenberg, 1844, p. $84=$ Eucyrtidium acuminatum (Ehrenberg) in Ehrenberg 1854b, pl. 22, fig. 27.

\section{Eucyrtidium (?) ptyctum Riedel and Sanfilippo} (Plate 2, Figure 5)

Eucyrtidium [?] ptyctum Riedel and Sanfilippo, 1974, p. 778, pl. 5, fig. 7 , pl 12, fig. 14,15 .

[?] Eucyrtidium (?) ptyctum Riedel and Sanfilippo in Pessagno, in press (b), pl. 12, fig. 7.

Remarks: The form illustrated in Pessagno (in press [b]) is only doubtfully included because it appears to have a cephalis and thorax with pores.

\section{Genus HSUUM Pessagno}

Hsuum Pessagno, in press (b). Type species (by original designation) Hsuum cuestaensis Pessagno, in press (b), pl. 7, fig. 12.

\section{Hsuum spp.}

(Plate 2, Figure 7)

Remarks: Included under this designation are all conical to cylindrical-conical forms with longitudinal ribs, very narrow segments, and little or no segmental constriction externally.

Although members of this genus are common in the material studied, poor preservation did not allow the individual species described by Pessagno to be recognized confidently and consistently. Rarely $H$. stanleyensis Pessagno and $H$. obispoensis Pessagno could be identified. The youngest form recognized belonging to this genus is Hsuum apiarum (Rust) which ranges upward well into the Eucyrtis tenuis Zone.

\section{Genus LITHOSTROBUS Bütschli}

Lithostrobus Bütschli, 1881, p. 529. Type species (subsequent designation by Campbell, 1954, p. D141) Eucyrtidium argus Ehrenberg, 1873, p. 225; 1875 , pl. 9, fig. 1.

\section{Lithostrobus litus Foreman, new species}

$$
\text { (Plate 4, Figure 12) }
$$

Stichocapsa sp. Kozlova in Petrushevskaya and Kozlova, 1972, pl. 8, fig. 7.

Lithostrobus sp. A Foreman, in press, pl. 1, fig. 9.

Description: The shell is conical to subcylindrical generally wide open distally, very rarely slightly constricted. There are no expressed external strictures. The large cephalis, probably with six collar pores, bears a short, bladed horn. Post cephalic segments expand gradually in width, their length varying according to the number of rows of pores, one to four on each segment. The pores are subround to rectangular; when rectangular the long axis is generally vertical, rarely transverse. Pores of adjacent segments are opposed and sometimes coalesce, otherwise the pores are quincuncially arranged. They tend to decrease in size on the distalmost segments.

Measurements (based on eight specimens from Hole 369A, Cores 36 and 37). Greatest number of segments $9+$; length of two specimens of nine segments each 250 and $280 \mu \mathrm{m}$, length of five segments 125 $175 \mu \mathrm{m}$; width of fifth segment $125-155 \mu \mathrm{m}$.

Remarks: In the material from Hole 369A specimens with segments bearing two rows of pores predominate. Similar forms observed from Hole 13A-3 are only doubtfully included because of their smaller size, common tendency for the last one or two segments to constrict, and the presence of weak longitudinal ridges. Two specimens with $6+$ segments measured $177 \mu \mathrm{m}$; the length of five segments on these two specimens were 140 and $165 \mu \mathrm{m}$; and their width was 100 and $115 \mu \mathrm{m}$. plain.

Etymology: The specific name is from the Greek adjective litos,

\section{Lithostrobus punctulatus (Pessagno) emend. Foreman} (Plate 4, Figure 11)

Lithostrobus (Lithostrobus) punctulatus Pessagno, 1963, p. 210 (partim), pl. 1, fig. 1; pl. 5, fig. 5 (?) (Not fig. 4).

Lithostrobus punctulatus Pessagno in Foreman, in press, pl. 1, fig. 6.

Description: The shell has six to eight preserved segments, is acutely conical proximally, continuing conical or becoming cylindrical distally and occasionally the last segment is slightly narrowed. The poreless cephalis is hyaline, subspherical and smooth except for varying numbers of tiny protrusions apically, one sometimes lengthened to form a small apical spine. Four collar pores are present at the collar stricture. The first two post-cephalic segments are rather short and have pores rather irregularly arranged. The remaining segments increase very gradually in length and have circular to elliptical pores very uniformly qunicuncially arranged to form diagonal and transverse rows, four to six transverse rows per segment. The first transverse row below each stricture sometimes has slightly larger pores than those on the remaining part of the segment. Shallow nodes to short sharp spines are present at the junctions of the intervening pore bars. When these are uniformly developed their spreading bases form diamond-shaped frames around the individual pores. At the strictures, narrow, angular, longitudinal, ridge-like nodes protrude between each set of opposed pores.

Measurements (based on 10 specimens from Sample 369A-38, CC and Cuba B191 Foreman [1971] where this species is particularly well developed). Length overall of specimens with $7+$ to $8+$ segments 210 $240 \mu \mathrm{m}$, length of six segments $140-150 \mu \mathrm{m}$; width of sixth segment $80-85 \mu \mathrm{m}$.

Remarks: The specimens measured appear to be remarkably uniform. Specimens at the upper end of their range from Hole $369 \mathrm{~A}$ tend to be conical throughout their length and have more robust longitudinal ridge-like nodes at the strictures. This form differs from Amphipyndax enesseffi with which it co-occurs in having a simple cephalis; pores larger and more regularly arranged; and angular, ridge-like nodes between each set of opposed pores at the strictures.

\section{Lithostrobus sp. aff. Lithostrobus rostovzevi Lipman}

(Plate 5, Figure 5)

Lithostrobus rostovzevi Lipman, 1960, p. 133, pl. 32, fig. 1-10, textfig. 9.

Remarks: The forms in this material differ from $L$. rostovzevi Lipman only in having thicker walls and normally thick intervening strictures. Sometimes this wall thickening appears to be a surface feature with groups of pores enclosed by ridges forming larger rounded superficial pores. The external shape of the cephalis, which internally has a branched vertical spine as in Foreman (1966, textfig. 4-6), is compatible with the external shape of $L$. rostovzevi. No indication of internal cephalic structures is given for $L$. rostovzevi. Specimens generally have five segments.

\section{Genus MYLLOCERCION Foreman}

Myllocercion Foreman, 1968, p. 37.

\section{Myllocercion spp. \\ (Plate 5, Figure 8)}

Remarks: Specimens of Myllocercion are absent or present in varying amounts throughout the Maestrichtian-Campanian sequence of Hole 369A. Rare complete forms indicate that both $M$. rhodanon 
and $M$. acineton are present. Generally, however, they are present without the distinguishing third segment and thus they have all been recorded as Myllocercion spp. on the occurrence table.

\section{Genus STICHOMITRA Cayeux}

Stichomitra Cayeux, 1897, p. 204. Type species (subsequent designation by Chediya, 1959, p. 232) Stichomitra costata Cayeux, 1897 , p. 204, pl. 8, fig. 68.

Remarks: It is not likely that this costate form is related to any of the species here assigned to the genus Stichomitra. The generic name is used here in the sense of Foreman (1968, p. 71).

\section{Stichomitra asymbatos group Foreman}

(Plate 4, Figure 15)

Stichomitra asymbatos Foreman, 1968, p. 73, pl. 8, fig. 10a-c.

\section{Stichomitra asymmetra Foreman n. sp.}

(Plate 5, Figure 2)

Stichomitra asymmetra Foreman, in press, pl. 1, fig. 10.

Stichomitra sp. cf. S. cathara Foreman in Johnson, 1974, pl. 1, fig. 13,14 .

(?) Lithocampe sp. A Dumitrica, 1973, p. 789, pl. 4, fig. 7; pl. 10, fig. 3 ; pl. 11 , fig. 3 .

Description: Shell of from five to eight segments plus a short narrow fragile tube. The first three to four segments are conical and the remainder cylindrical with the last segment before the tube generally slightly narrowed and less sturdy than the preceding segments. The small cephalis may bear a short slender apical horn or have the cephalic wall thickened at the apex. The lumbar stricture is generally not horizontal and thus the cephalis and thorax frequently appear askew. Cephalis and thorax are both poreless except for an occasional specimen which may have a few pores at the lumbar stricture. The remaining segments have small, widely spaced, rounded pores, generally irregularly arranged and recessed in angular frames. These frames result in a rough surface and on the distal segments give rise to nodes or occasional downward directed spines at their junctures. The tube is frequently broken off, but when present is thinwalled with rounded pores, irregularly arranged or tending toward transverse alignment.

Measurements (based on 10 specimens from Hole 369A, Cores 36 and 37). Length of longest complete specimen $130 \mu \mathrm{m}$, of five segments $85-100 \mu \mathrm{m}$; greatest width $50-70 \mu \mathrm{m}$, width of tube $30-35$ $\mu \mathrm{m}$.

Remarks: A related form (Plate 5, Figure 1) from the California Academy of Science locality 39545 Alameda Co., California, differs in having more closely spaced, more numerous pores without frames and thus a smoother surface. These specimens also tend to have more segments, be less regular in width, and lack spines.

Etymology: The specific name is from the Greek adjective asymmetros, without symmetry.

\section{Stichomitra compsa Foreman}

(Plate 5, Figure 3)

Stichomitra compsa Foreman, 1968, p. 72, pl. 8, fig. 8a, b.

Remarks: See "Remarks" under Stichomitra manifesta.

\section{Stichomitra manifesta Foreman, n. sp. (Plate 5, Figure 4)}

Diacanthocapsa sp. B Kozlova in Petrushevskaya and Kozlova, 1972, p. 536, pl. 7 , fig. 5 .

Stichomitra sp. A Foreman, in press, pl. 1, fig. 11

Description: This robust species is here generally preserved with four or five segments. Rare specimens have only three, and one specimen has as many as seven. The cephalis is small, subspherical, and may have widely spaced ridges which join the angular pore frames that encircle the small, rounded, widely spaced pores of the thorax. The thorax is characteristically hemispherical, generally greater in length than the next succeeding segment. The post-thoracic segments have relatively large rounded pores set in angular frames, irregular in size and arrangement, except for some specimens on which the pores show a distinct tendency towards transverse alignment. The pores increase gradually in size distally except between the thorax and the first succeeding segment where there is a marked change in pore size.

Measurements (based on 10 specimens from Hole 369A, Cores 36 and 37). Length of one specimen with seven segments $210 \mu \mathrm{m}$, of four specimens of five segments $140-170 \mu \mathrm{m}$.
Remarks: This species may be distinguished from specimens of $S$. compsa with large pores, with which it co-occurs, by its larger, hemispherical thoracic segment. Compare Figures 3 and 4 on Plate 5.

Etymology: The specific name is from the Latin adjective manifestus, clear, visible.

Genus STICHOPILIDIUM Haeckel, emend.

Stichopilidium Haeckel, 1887; emend. Foreman, 1968, p. 70.

Stichopilidium teslaense Campbell

Stichopilidium teslaense Campbell, in Foreman, 1968, p. 70, pl. 8 , fig. 13.

Genus THEOCAPSOMMA Haeckel, emend.

Theocapsomma Haeckel, 1887; emend. Foreman, 1963, p. 29.

\section{Theocapsomma comys group Foreman}

\author{
(Plate 5, Figures 11, 12)
}

Theocapsomma comys Foreman, 1968, p. 29, pl. 4, fig. 2a-c.

Remarks: Theocapsomma comys as originally described from the late Maestrichtian has not been observed in any of numerous early Maestrichtian or late Campanian samples examined. In many samples, however, there are forms with the first two segments very like $T$. comys and the abdomen completely or partly broken off. In some of the samples where these broken forms occur, rare forms with complete abdomens have always proved to differ from $T$. comys in having less regularly disposed pores on the abdomen, pores differing in size from those on the thorax, an abdominal aperture, or a combination of two or more of these features (Plate 5, Figure 12). This variety of three segmented forms with pores in regular vertical rows on the thorax is defined as the Theocapsomma comys group. In the material from Hole 369A no complete forms of $T$. comys have been observed; only specimens with no, or a small fragment of the abdomen present occur. Thus these forms are all recorded as belonging to the Theocapsomma comys group.

It is here considered that the definition of the Theocapsomma comys Zone of Riedel and Sanfilippo, which is defined as the first appearance of Theocapsomma comys Foreman, actually refers to the first appearance of the Theocapsomma comys group.

\section{Theocapsomma teren Foreman}

(Plate 5, Figure 7)

Theocapsomma teren Foreman, 1968, p. 32, pl. 4, fig. 4.

\section{Theocapsomma sp. aff. T. comys Foreman}

$$
\text { (Plate 5, Figure 10) }
$$

Remarks: This interesting form, although very rare, is illustrated and tabulated because of its apparent restricted range and robust shell. It differs from $T$. comys by the very large size of its pores. The distal half of the abdomen has not been seen.

Gen. and sp. indet.

(Plate 2, Figure 4)

cf. Gen. and sp. indet. Foreman, 1971, p. 1676, pl. 3, fig. 1.

Remarks: This form from Hole 367 is basically an ellipsoid with a small, partly enclosed cephalis and a small, round aperture distally. There are approximately nine longitudinal ridges or undulations per half a circumference. It is not certain if the post-cephalic part is divided into two or more segments which without external strictures could not be distinguished in this material, or, as in the form illustrated by Foreman (1971), is composed of only one segment. This post-cephalic part appears to be poreless, though this may be the result of the poor preservation.

\section{Subfamily SYRINGOCAPSINAE Foreman, 1973}

Genus PODOBURSA Wiśniowski, emend.

Podobursa Wiśniowski, 1889, emend. Foreman, 1973, p. 266.

\section{Podobursa triacantha (Fischli)}

Podobursa triacantha (Fischli) in Foreman, 1973, p. 266, pl. 13, fig. 1-7.

Remarks: This species continues to be defined very broadly as in Foreman, 1973. 


\section{Podobursa pantanellii (Parona)}

(Plate 1, Figure 17)

Podocapsa pantanellii Parona, 1890 , p. 164 , pl. 5, fig. 8 .

Indeterminatum Heitzer, 1930, p. 387, pl. 27, fig. 7.

Podobursa pantanellii (Parona) in Riedel and Sanfilippo, 1974, p. 779 , pl. 8 , fig. 5 ; pl. 13, fig. 6 .

Podobursa berggreni Pessagno, in press (b), pl. 12, fig. 1-5.

Remarks: The distinctive branched spine and tube terminations make this a very easily recognized form.

Genus PODOCAPSA Rüst, emend.

Podocapsa Rüst, 1885, p. 304; emend. Foreman, 1973, p. 267.

\section{Podocapsa amphitreptera Foreman}

(Plate 1, Figure 16)

Podocapsa amphitreptera Foreman, 1973, p. 267, pl. 13, fig. 11; 1975 , p. 617 , pl. 6 , fig. 15 .

Remarks: Later specimens tend to have the globose segment larger and more inflated than do earlier ones. See Foreman, 1973, 1975.

\section{Genus SETHOCAPSA Haeckel}

Sethocapsa Haeckel, 1881, Foreman, 1973, p. 267.

\section{Sethocapsa cetia Foreman}

(Plate 2, Figure 1)

Sethocapsa cetia Foreman, 1973, p. 268, pl. 12, fig. 1; pl. 16, fig. 19; Foreman, 1975, p. 617, pl. 6, fig. 14.

[?] Obesacapsula cetia (Foreman) in Pessagno, in press (b), pl. 11, fig. 4.

Remarks: Obesacapsula cetia is only doubtfully included, because it lacks well-developed nodes and terminates in a broad tube, both features which have not been observed in this species heretofore.

\section{Sethocapsa trachyostraca Foreman} (Plate 1, Figure 18)

Sethocapsa trachyostraca Foreman, 1973, p. 268, pl. 12, fig. 4; 1975, p. 617 , pl. 2J, fig. 3,4 .

\section{Sethocapsa sp. cf. Theocapsa uterculus Parona}

(Plate 2, Figure 8)

Sethocapsa spp. cf. Theocapsa uterculus Parona in Foreman, 1975, p. 617 , pl. 2I, fig. 21, 22.

\section{Genus SYRINGOCAPSA Neviani}

Syringocapsa Neviani, 1900. Type species (by monotypy) Theosyringium robustum Vinassa, 1900, p. 343, pl. 3, fig. 30 .

\section{Syringocapsa rotunda (Hinde)}

(Plate 2, Figure 2)

Stichocapsa (?) rotunda Hinde in Foreman, 1975, p. 616, pl. 2J, fig. 6 ; pl. 7 , fig. 5 .

Remarks: In the description of this species Foreman (1973, p. 265) stated "no aperture is apparent." Since then, both in the material examined from DSDP Leg 32 and Leg 41, a slender cylindrical distalmost part has been observed to extend from the large subglobose abdomen, and thus the generic assignment has been changed.

\section{Radiolaria of uncertain affinities}

\section{Genus ACIDNOMELOS Foreman}

Acidnomelos Foreman, 1968, p. 24.

\section{Acidnomelos proapteron Foreman, n. sp.}

$$
\text { (Plate 5, Figure 13) }
$$

Acidnomelos proapteron Foreman, in press, pl. 1, fig. 12.

Description: Shell of two segments, subcylindrical. The cephalis is approximately hemispherical, poreless, except for a vertical pore, and a sharp apical spine which may be slender or very broad based. Externally the collar stricture is marked by no or only a very slight change in contour. The thorax is cylindrical, smooth except for ridges which are very variably developed on individual specimens. Some extend as a group of two or three from the apical spine to the base of a foot where they coalesce to form a blade on the foot. Others are developed as single ridges beginning to be expressed anywhere from the apical spine to about midway along the length of the thorax. Sometimes the ridges are barely visible. Pores are small, circular, widely and irregularly spaced.

Measurements (based on 10 specimens from Hole 369A, Cores 38 and 39). Length overall, including horn and feet $130-190 \mu \mathrm{m}$, length of cephalis and thorax 100-140 $\mu \mathrm{m}$; greatest width $55-75 \mu \mathrm{m}$.

Remarks: This form is closely related to, and may be considered as the ancestor of Acidnomelos apteron reported from the late Maestrichtian of California. It differs from that form in having a more cylindrical throax and feet originating from ridges on the shell. When the ridges are entirely missing this form passes to $A$. apteron.

Etymology: The specific name is from the Greek preposition pro, before, and the species name apteron, which was derived from the Greek adjective apteros, without wings.

\section{Genus LITHOMELISSA Ehrenberg}

Lithomelissa Ehrenberg, 1847b. Type species (by subsequent monotypy) Lithomelissa microptera Ehrenberg, 1854b, pl. 36, fig. 2.

\section{Lithomelissa (?) heros Campbell}

(Plate 5, Figure 14)

(?) Lithomelissa heros Campbell in Foreman, 1968, p. 25, pl. 3, fig. $5 a, b$; text-fig. I, fig. 7 .

\section{Lithomelissa (?) hoplites Foreman}

(Plate 5, Figure 9)

(?) Lithomelissa hoplites Foreman, 1968, p. 26, pl. 3, fig. 2a-c. Lithomelissa (?) hoplites Foreman, in press, pl. 1, fig. 7.

\section{Genus LOPHOPHAENA Ehrenberg}

Lophophaena Ehrenberg, 1847b, p. 54. Type species (by subsequent monotypy) Lophophaena galeaorci Ehrenberg, 1854a, p. 245.

Lophophaenula Haeckel, 1887, p. 1303. Junior objective synonym of Lophophaena Ehrenberg, 1847b.

\section{Lophophaena (?) polycyrtis (CampbelI)} (Plate 5, Figure 20)

(?) Lophophaena polycyrtis (Campbell) in Foreman, 1968, p. 23, pl. 3, fig. 3a-c.

Lophophaena (?) polycyrtis (Campbell) in Foreman, in press, pl. 1, fig. 8 .

\section{Genus RHOPALOSYRINGIUM Campbell emend.}

Rhopalosyringium Campbell in Campbell and Clark, 1944, p. 30. Type species (by original designation) Rhopalosyringium magnificum Campbell in Campbell and Clark, 1944, p. 30, pl. 7, fig. 16, 17; emend. Foreman, 1968, p. 54.

\section{Rhopalosyringium antirrhopum Riedel and Sanfilippo} (Plate 5, Figure 16)

Rhopalosyringium antirrhopum Riedel and Sanfilippo, 1974, p. 780, pl. 9, fig. 13; pl. 13, fig. 8-10.

Remarks: Only three specimens of this form were observed in Samples 35, CC and 37-1, 141-143 cm, from the MaestrichtianCampanian sequence of Hole 369A.

\section{Rhopalosyringium colpodes Foreman}

(Plate 5, Figure 18)

Rhopalosyringium colpodes Foreman, 1968, p. 57, pl. 6, fig. 6 .

Rhopalosyringium sp. aff. $R$. colpodes Kozlova in Petrushevskaya and Kozlova, 1972, p. 537, pl. 7, fig. 12.

\section{Rhopalosyringium sparnon Foreman \\ (Plate 5, Figure 17)}

Rhopalosyringium sparnon Foreman, 1968, p. 56, pl. 6, fig. 5.

\section{Incertae Sedis}

\section{Genus AFENS Riedel and Sanfilippo}

Afens Riedel and Sanfilippo, 1974, p. 775. Type species (by monotypy) Afens lirioides Riedel and Sanfilippo, 1974, p. 775, pl. 13 , fig. 15 . 
Afens liriodes Riedel and Sanfilippo

(Plate 5, Figure 24)

Afens liriodes Riedel and Sanfilippo, 1974, p. 775, pl. 11, fig. 11; pl. 13, fig. 14-16.

\section{ACKNOWLEDGMENTS}

The author wishes to thank David Johnson for arranging for the shipboard sampling. Financial support for this work was provided by the Oceanography section, National Science Foundation, Grant DES 75-19288.

\section{REFERENCES}

Burma, B.H., 1959. On the status of Theocampe Haeckel, and certain similar genera: Micropaleontology, v. 5, p. 325330.

Bütschli, Otto, 1881. Beiträge zur Kenntnis der Radiolarienskelett, insbesondere der Cyrtida: Z. Wiss. Zool., v. 36, p. $485-540$.

Campbell, A.S., 1954. Radiolaria. In Moore, R.C. (Ed.), Treatise on invertebrate paleontology, Part D. Protista 3. Protozoa (chiefly Radiolaria and Tintinnina): Geol. Soc. Am. and Univ. Kans. Press, Lawrence, p. D11-D163.

Campbell, A.S. and Clark, B.L., 1944. Radiolaria from Upper Cretaceous of middle California: Geol. Soc. Am., Spec. Paper 57.

Cayeux, L., 1897. Contribution à l'étude micrographique des terrains sédimentaires. 1. Etude de quelque dépôts siliceux secondaires et tertiaires du Bassin de Paris et de la Belgique. 2. Craie du Bassin de Paris: Soc. Géol. Nord, Mém., Lille, v. 4, p. 1-591.

Chediya, D.M., 1959. Obzor sístematiki Radioliarii (Obseryation on the systematics of the Radiolaria): Tadzhikskii Gosudarstvennyi Universitet, Stalingrad, p. 1330.

Deflandre, G., 1953. Radiolaries fossiles. In Grassé, P.-P. (Ed.), Traité de Zoologie: Paris (Masson), v. 1, p. 389436.

Dumitrica, P., 1973. Paleocene Radiolaria, DSDP Leg 21. In Burns, R.E., Andrews, J.E., et al., Initial Reports of the Deep Sea Drilling Project, Volume 21: Washington (U.S. Government Printing Office), p. 787-817.

Dunikowski, E. v., 1882. Die Spongien, Radiolarien und Foraminiferen der unterliassischen Schichten vom Schafberg bei Salzburg: K. Akad. Wiss., Wein, Denkschr., v. 45 , p. $163-195$.

Ehrenberg, C.G., 1844. Uber 2 neue Lager von Gebirgsmassen aus Infusorien als Meeres-Absatz in NordAmerika und eine Vergleichung derselben mit den organischen Kreide-Gebilden in Europa und Afrika: Kgl. Preuss. Akad. Wiss. Berlin, Ber., Jahre 1844, p. 57-97. 1847a. Uber eine halibiolithische, von Herrn R. Schomburgk entdeckte, vorherrschend aus mikroskopischen Polycystinen gebildete, Gebirgsmasse von Barbados: Kgl. Preuss. Akad. Wiss. Berlin, Ber., Jahre 1846 , p. $382-385$.

1847b. Uber die mikroskopischen kieselschaligen Polycystinen als mächtige Gebirgsmasse von Barbados und über das Verhältniss der aus mehr als 300 neuen Arten bestehenden ganz eigenthümlichen Formengruppe jener Felsmasse zu den jetzt lebenden Thieren und zur Kreidebildung. Eine neue Anregung zur Erforschung des Erdlebens: Kgl. Preuss. Akad. Wiss. Berlin, Ber., Jahre 1847 , p. $40-60$.

, 1854a. Die systematische Charakteristik der neuen mikroskopischen Organismen des tiefen atlantischen Oceans: Kgl. Preuss. Akad. Wiss. Berlin, Ber., Jahre 1854, p. $236-250$.

1854b. Mikrogeologie: Leipzig (Voss), xxviii +374 p.; Atlas, 31 p., 41 pl.; Fortsetzung (1856), 88 p.
1873. Grössere Felsproben des Polycystinen-Mergels von Barbados mit weiteren Erläuterungen: $\mathrm{Kgl}$. Preuss. Akad. Wiss. Berlin, Monatsber., Jahre 1873, p. 213-263.

, 1875. Fortsetzung der mikrogeologischen Studien als Gesammt-Uebersicht der mikroskopischen Paläontologie gleichartig analysirter Gebirgsarten der Erde, mit specieller Rücksicht auf den PolycystinenMergel von Barbados: Kgl. Akad. Wiss. Berlin, Abh., Jahre 1875 , p. 1-225.

Foreman, H.P., 1966. Two Cretaceous radiolarian genera: Micropaleontology, v. 12, p. 355-359.

1968. Upper Maestrichtian Radiolaria of California: Palaeontol. Assoc., London, Spec. Paper 3, p. iv $+1-82$.

1971. Cretaceous Radiolaria. In Winterer, E.L., Riedel, W.R., et al., Initial Reports of the Deep Sea Drilling Project, Volume 7: Washington (U.S. Government Printing Office), p. 1673-1693.

1973. Radiolaria from DSDP Leg 20. In Heezen, B.C., MacGregor, I.D., et al., Initial Reports of the Deep Sea Drilling Project, Volume 20: Washington (U.S. Government Printing Office), p. 249-305.

1975. Radiolaria from the North Pacific, Deep Sea Drilling Project, Leg 32. In Larson, R.L., Moberley, R., et al., Initial Reports of the Deep Sea Drilling Project, Volume 32: Washington (U.S. Government Printing Office), p. 579-676, 24 pls.

, in press. Mesozoic Radiolaria from the Atlantic Basin and its borderlands: Univ. Delaware Symp. Micropaleontol. of the Atlantic Basin and its Borderlands.

Foreman, H.P. and Riedel, W.R., in press. Polycystine Radiolaria 1834-1930. v. 1.

Frizzell, D.L. and Middour, E.S., 1951. Paleocene Radiolaria from southeastern Missouri: Univ. Missouri School Mines, Tech. Ser., no. 77.

Haeckel, E., 1860. Fernere Abbildungen und Diagnosen neuer Gattungen und Arten von Lebenden Radiolarien des Mittelmeeres: Kgl. Preuss. Akad. Wiss. Berlin, Monatsber., Jahre 1860 , p. 835-845.

1862. Die Radiolarien (Rhizopoda Radiaria): Berlin (Reimer), xiv + 572 p.; Atlas; IV p + 35 pl. 1879. Natürliche Schöpfungsgeschichte: Berlin (Reimer), 718 p., 17 pl. 1881. Entwurf eines Radiolarien-Systems auf Grund von Studien der Challenger-Radiolarien: Jena. Z. Med. Naturwiss., v. 15 (new ser., v. 8), p. 418-472.

1887. Report on the Radiolaria collected by H.M.S. Challenger during the years 1873-1876: Rept. Sci. Result. Voyage H.M.S. Challenger, Zool., v. 18.

Heitzer, I., 1930. Die Radiolarienfauna der mitteljurassischen Kieselmergel im Sonnwendgebirge: Austr., Geol. Bundesanst., Jahrb., v. 80, p. 381-406.

Johnson, D.A., 1974. Radiolaria from the Eastern Indian Ocean, DSDP Leg 22. In von der Borch, C.C., Sclater, J.G., et al., Initial Reports of the Deep Sea Drilling Project, Volume 22: Washington (U.S. Government Printing Office), p. 521-575.

Kozlova, G.E., 1972. (See Petrushevskaya and Kozlova, 1972.)

Kozlova, G.E. and Gorbovetz, A.N., 1966. Radiolarii verkhnemelovykh i verkhneéotsenovykh otlozhenii zapadno- Sibirskoi nizmennosti. (Radiolarians of the Upper Cretaceous and upper Eocene deposits of the west Siberian lowland.): Trudy VNIGRI, no. 248 , p. 1-159.

Lipman, R.K., 1952. Materialy k monographicheskomu izucheniiu radioliarii verkhnemelovykh otlozhenii russkoi platformy. (Data on the monographic study of the radiolarians of the Upper Cretaceous deposits of the Russian plateau.): Trudy VSEGEI, Paleontol. Strat., p. 24-51. 
1960. Stratigrafiya i fauna melovykh otlozhenii zapadno-Sibirskoi nizmennosti. (Stratigraphy and fauna of the Cretaceous deposits in the western Siberia lowland.): Trudy VSEGEI, new ser., v. 29, p. 124-134.

Loeblich, A.R., Jr., and Tappan, Helen, 1961. Remarks on the systematics of the Sarkodina (Protozoa), renamed homonyms and new and validated genera: Biol. Soc. Wash., Proc., v. 74, p. 213-234.

Neviani, A., 1900. Supplemento alla fauna a Radiolari delle rocce mesozoiche del Bolognese: Soc. Geol. Ital., Boll., v. 19, p. $645-670$.

Parona, C.F., 1890. Radiolarie nei noduli, selciosi del calcare giurese di Cittiglio presso Laverno: Soc. Geol. Ital., Boll., v. 9 , p. 132-175.

Pessagno, E.A., Jr., 1963. Upper Cretaceous Radiolaria from Puerto Rico: Micropaleontology, v. 9, p. 197-214.

1971. Jurassic and Cretaceous Hagiastridae from the Blake-Bahama Basin (Site 5A, JOIDES Leg I) and the Great Valley sequence, California Coast Ranges: Bull. Am. Paleontol., v. 60, p. 1-83.

1972a. Pt. 1: The Phaseliformidae, new family, and other Spongodiscacae from the Upper Cretaceous portion of the Great Valley sequence. In Cretaceous Radiolaria: Bull. Am. Paleontol., v. 61, p. 267-280, 316-317, 326-328. 1972b. Pt. 2: Pseudaulophacidae Riedel from the Cretaceous of California and the Blake-Bahama Basin (JOIDES Leg I). In Cretaceous Radiolaria: Bull. Am. Paleontol., v. 61, p. 281-314, 318-328. 1973. Upper Cretaceous Spumellariina from the Great Valley sequence, California Coast Ranges: Bull. Am. Paleontol., v. 63, p. 49-102.

, in press (a). Radiolarian zonation and stratigraphy of the Upper Cretaceous portion of the Great Valley sequence, California Coast Ranges.

in press (b). Upper Jurassic Radiolaria and radiolarian biostratigraphy of the California Coast Ranges.

Petrushevskaya, M.G. and Kozlova, G.E., 1972. Radiolaria: Leg 14, Deep Sea Drilling Project. In Hayes, D.E., Pimm, A.C., et al., Initial Reports of the Deep Sea Drilling Project, Volume 14: Washington (U.S. Government Printing Office), p. 495-648.

Riedel, W.R., 1967a. Some new families of Radiolaria: Geol. Soc. London, Proc., no. 1640, p. 148-149. 1967b. Protozoa [Subclass Radiolaria]. In Harland, W.B., et al. (Eds.), The fossil record: London (Geol. Soc. London), p. 291-298.

Riedel, W.R. and Sanfilippo, A., 1974. Radiolaria from the southern Indian Ocean, DSDP Leg 26. In Davies, T.A., Luyendyk, B.P., et al., Initial Reports of the Deep Sea Drilling Project, Volume 26: Washington (U.S. Government Printing Office), p. 771-814.

Rüst, D., 1885. Beiträge zur Kenntniss der fossilen Radiolarien aus Gesteinen des Jura: Palaeontographica, v. 31, ser. 3, p. 273-321.

1898. Neue Beiträge zur Kenntniss der Fossilen Radiolarien aus Gesteinen des Jura und der Kreide: Palaentographica, v. 45, p. 1-67.

Squinabol, S., 1903. Le Radiolaire dei noduli selciosi nella Scaglia degli Euganei. Contribuzione I: Riv. Ital. Paleontol., v. 9, p. 105-151.

1914. Contributo alla conoscenza dei Radiolarii fossili del Veneto. Appendice-Di un genere di Radiolari caratteristico del Secondario: Padova, R. Univ. Ist. Geol. Mem., v. 2, p. 249-306.

Tan Sin Hok, 1927. Over de samenstelling en het onstaan van krijt-en mergelgesteenten van de Molukken. (On the composition and origin of chalks and marls in the Moluccas.) In Brouwer, H.A. (Ed.), Geologische onderzoekingen in den oostelijken Oost-Indischen Archipel. V. (Geological investigations in the eastern East Indian Archipelago. V.): Jaarb. Mijnwez. Ned. Oost-Indië, v. 55 (1926), pt. 3 , p. $3-165$.

Vinassa de Regny, P.E., 1900. Rocce e fossili dei dintorni di Grizzana e di Lagàro nel Bolognese: Soc. Geol. Ital., Boll., v. 19 , p. $321-348$.

Wiśniowski, T., 1889. Beitrag zur Kenntniss der Mikrofauna aus der oberjurassischen Feuersteinknollen der Umgegend von Krakau: Kaiserl.-Kgl. Geol. Reichsanst., Jahrb., v. 38 (4), Jahrg. 1888, p. 657-702.

Yao, A., 1972. Radiolarian fauna from the Mino Belt in the northern part of the Inuyama Area, central Japan: J. Geosci., v. 15, p. 21-65.

Zittel, K.A., 1876. Ueber einige fossile radiolarien aus der norddeutschen Kreide: Deut. Geol. Ges. Z., v. 28, p. 7586. 


\section{PLATE 1}

All figures are magnified $\times 113$.

Figures 1,2 Emiluvia pessagnoi.

1. Sample 367-36-3, 49-51 cm. Cs. 1, K18/0.

2. Sample $367-36-3,49-51 \mathrm{~cm}$. Cs. $1, \mathrm{~W} 13 / 0$.

Figure 3 Emiluvia hopsoni.

Sample 367-35-2, $42-44 \mathrm{~cm}$. Cs. 1, V46/1.

Figure 4 Emiluvia chica.

Sample 367-37-1, 147-149 cm. Cs. 2, M34/0.

Figures 5,6 Paronaella (?) diamphidia.

5. Sample 367-37-1, 80-82 cm. Sl. A, S19/2.

6. Sample 367-37-1, 80-82 cm. Fn. A2, F38/1.

Figure 7 Acanthocircus dicranacanthos.

Sample 367-31-1, 49-50 cm. Fn. 1, T21/2.

Figure $8 \quad$ Acanthocircus sp. cf. Spongosaturnalis (?) suboblongus.

Sample 367-37-1, 147-149 cm. Sl. 2, M23/0.

Figure $9 \quad$ Acanthocircus trizonalis (?).

Sample 367-35-2, 28-31 cm. Fn. 1, L26/4.

Figure $10 \quad$ Member of Sphaerostylus lanceola group. Sample 367-37-1, 80-82 cm. Sl. B, M25/2.

Figure 11 Ancestral Sphaerostylus lanceola.

Sample 367-37-1, 80-82 cm. Fn. A2, J22/3.

Figure 12 Archaeospongoprunum imlayi.

Sample 367-37-1, 80-82 cm. Fn. A2, U35/4.

Figures 13, 14 Triactoma jonesi.

13. Sample $367-35-2,42-44 \mathrm{~cm}$. Cs. $1, \mathrm{~L} 14 / 1$.

14. Sample $367-35-2,42-44 \mathrm{~cm}$. Cs. $1, \mathrm{X} 33 / 0$.

Figure 15 Triactoma blakei.

Sample 367-37-1, 147-149 cm. Cs. 2, J12/4.

Figure $16 \quad$ Podocapsa amphitreptera.

Sample 367-35-2, 42-44 cm. Cs. 2, T35/0.

Figure 17 Podobursa pantanellii.

Sample 367-36-3, 49-51 cm. Cs. 1, X30/0.

Figure 18 Sethocapsa trachyostraca.

Sample 367-29-2, 26-27 cm. Cs. 1, J18/4. 
PLATE 1

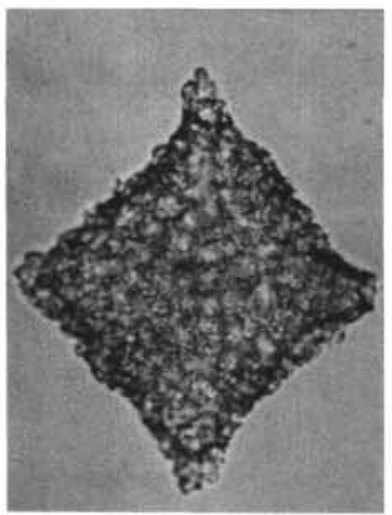

1
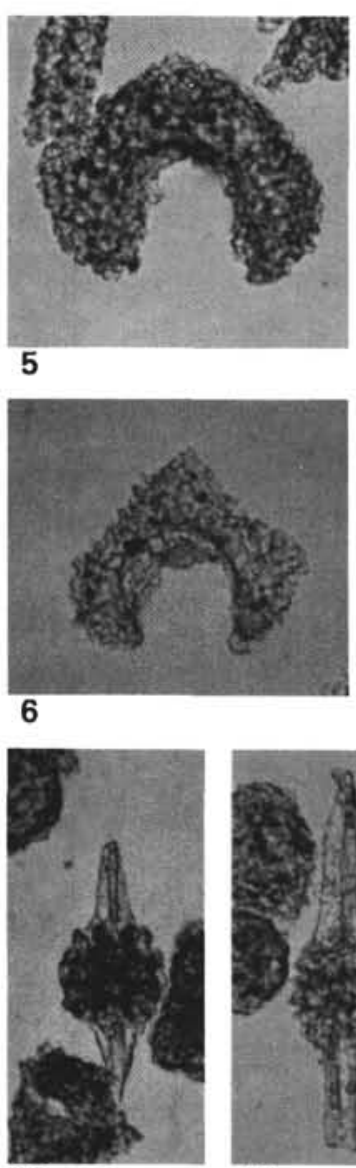

10

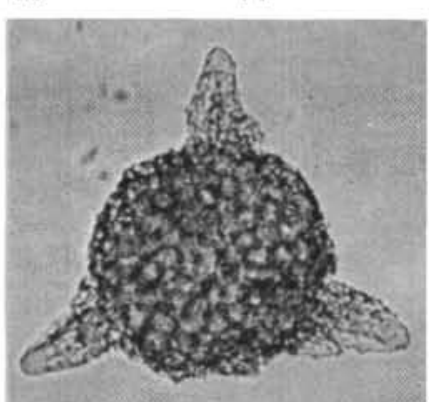

15

7
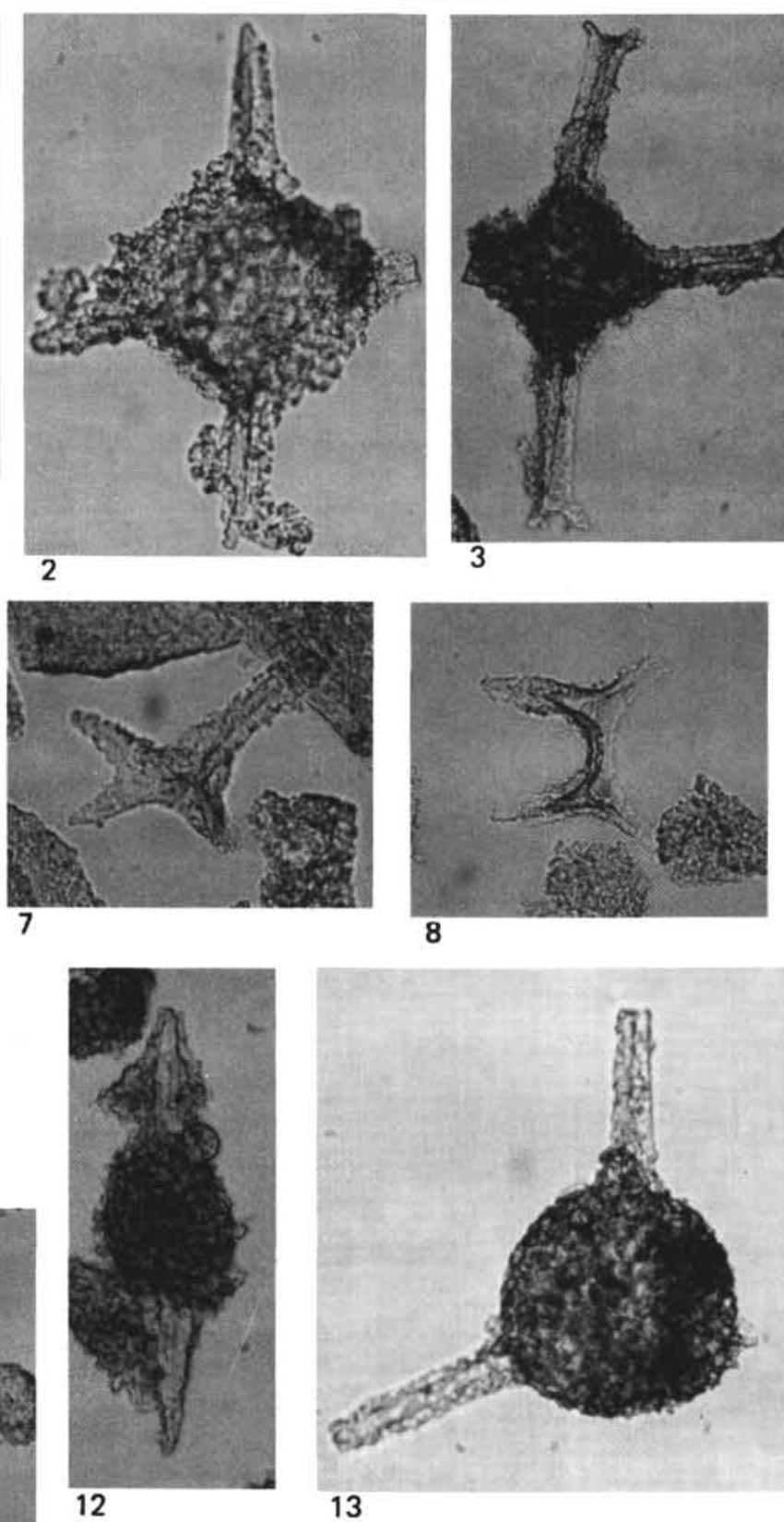

13
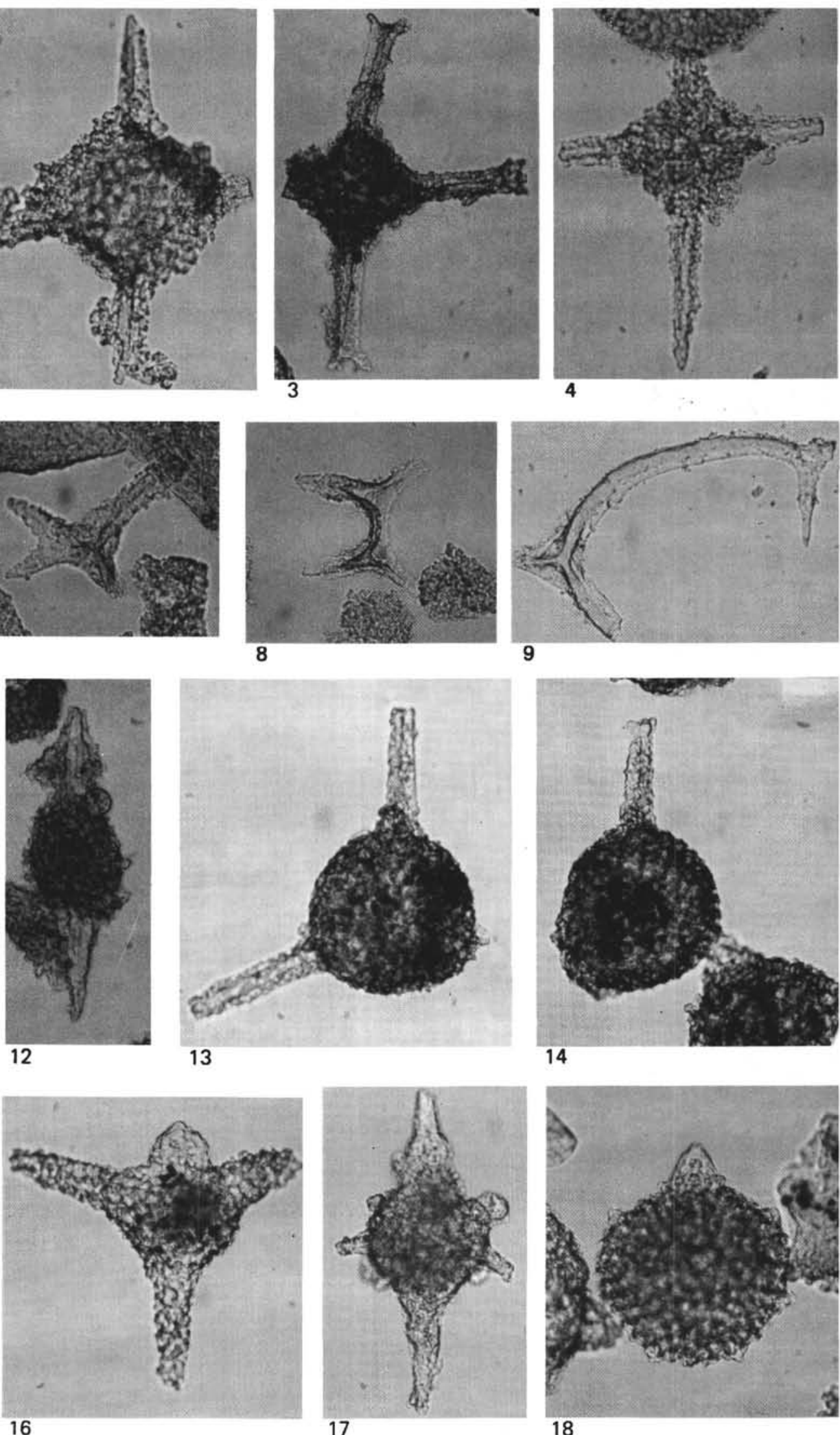

17

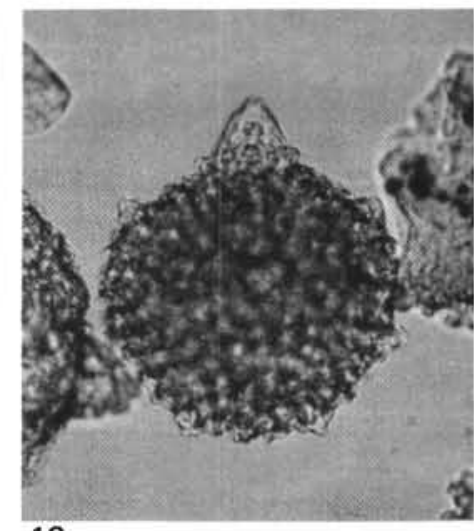




\section{PLATE 2}

Figures $1-8$ are magnified $\times 113$

Figures 9-18 are magnified $\times 214$

Figure 1 Sethocapsa cetia.

Sample 367-35-2, 42-44 cm. Cs. 1, O18/4.

Figure 2 Syringocapsa rotunda.

Sample 367-29-2, 26-27 cm. Cs. 1, V39/2.

Figure $3 \quad$ Mirifusus mediodilatata s.l.

Sample 367-32-4, 90-92 cm. Sl. 1, B26/0.

Figure 4 Gen. and sp. indet.

Sample 367-36-3, 49-51 cm. Fn. 1, S41/3.

Figure $5 \quad$ Eucyrtidium (?) ptyctum.

Sample 367-35-2, 28-31 cm. Fn. 1, U12/0.

Figure $6 \quad$ Mirifusus boesii.

Sample 367-35-2, 42-44 cm. Cs. 1, Q36/2.

Figure $7 \quad$ Hsuum sp. cf. H. stanleyensis.

Sample 367-35-2, 28-31 cm. Fn. 1, U40/3.

Figure $8 \quad$ Sethocapsa sp. cf. Theocapsa uterculus.

Sample 367-29-2, 26-27 cm. Fn. 2, V43/2.

Figures 9, 10, Ellipsoxiphus pusilla.

9. CAS loc. 39545 . St. $1490, \mathrm{~N} 50 / 2$.

10. CAS loc. 39545 . St. $1490, \mathrm{O} 27 / 2$.

17. Sample 369 A-37-1, 141-143 cm. Sl. 1, O38/3.

Figure 11 Archaeospongoprunum sp. cf. A. cortinaensis.

Sample 369A-37-4, 65-69 cm. Sl. 1, Q32/2.

Figure 12 Archaeospongoprunum hueyi.

Sample 369A-37, CC. SI. 2, N22/4.

Figure 13 Ellipsoxiphus hastatus.

Sample 369A-38, CC. SI. 1, K34/0.

Figures 14-16 Ellipsoxiphus privus.

14. Sample 369A-39, CC. Fn. 1, F22/4.

15. Sample 369A-38, CC. Sl. 1, L31/4. Holotype, USNM 243114.

16. Sample 369A-38, CC. Sl. 1, N21/1.

Figure 18 Cromyodruppa (?) concentrica.

Sample 369A-35, CC. S1. 4, T22/4.

Figure 19 Gen. and sp. indet.

Sample 369A-37, CC. Sl. 2, S19/3.

Figure $20 \quad$ Triactinosphaera morenoensis.

Sample 369A-37, CC. Sl. 2, M31/0.

Figure $21 \quad$ Gen. and sp. indet.

Sample 369A-37, CC. Sl. 2, P34/3. 
PLATE 2

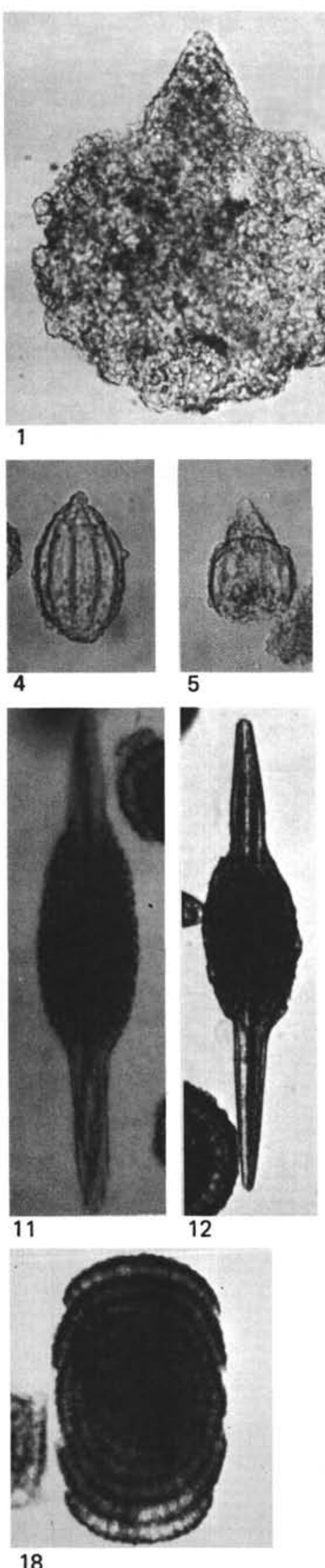

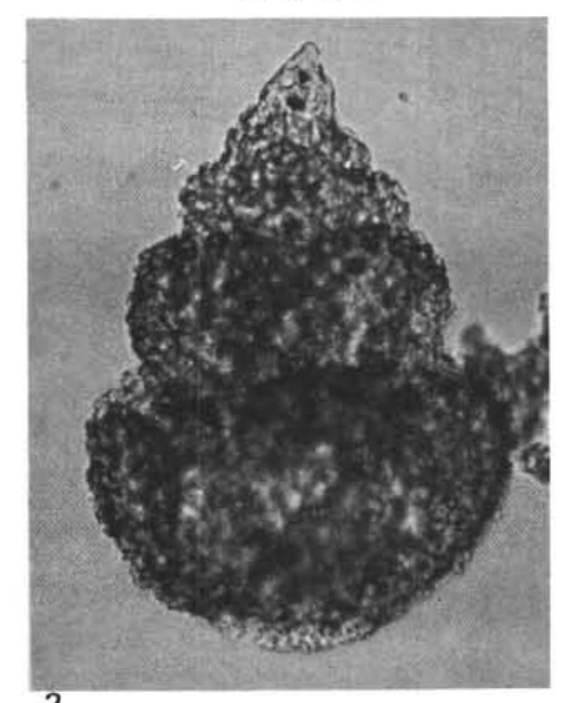
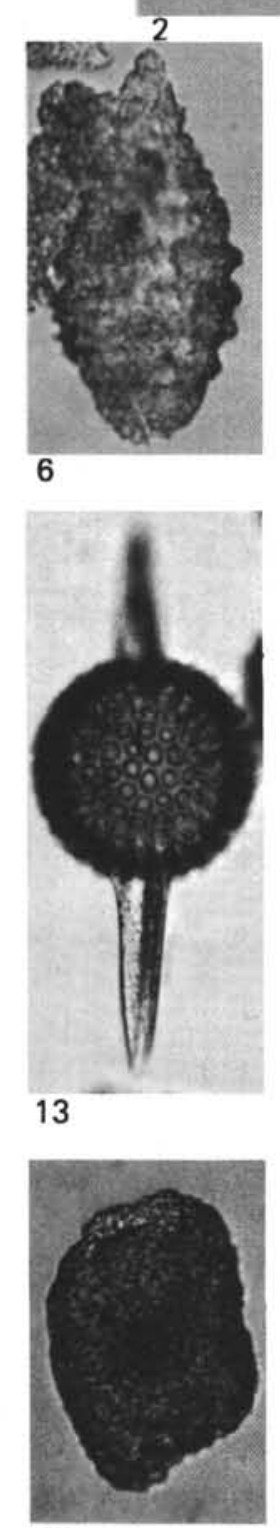

19
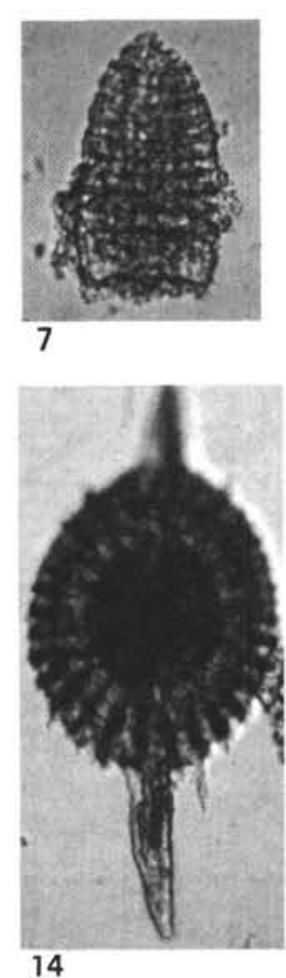
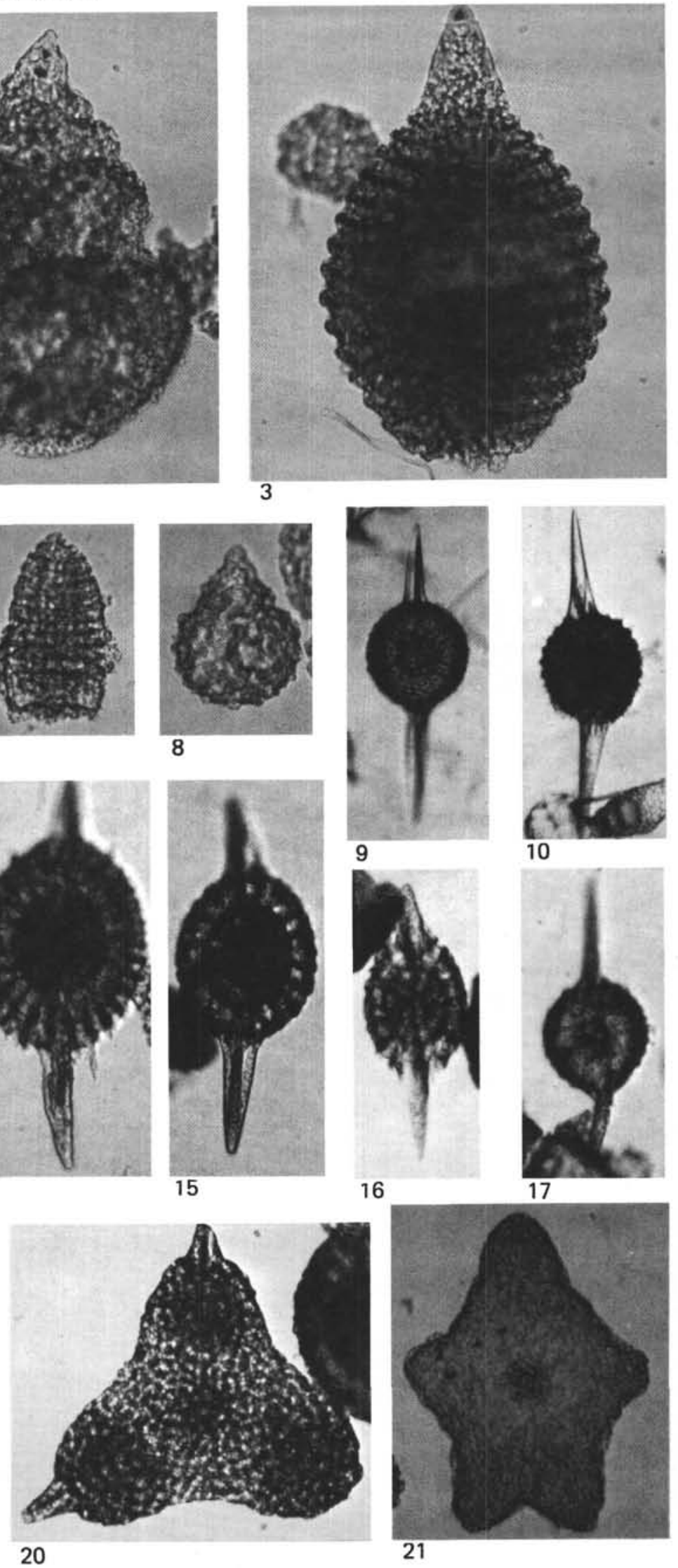


\section{PLATE 3}

All figures are magnified $\times 214$

Figures 1, 2 Alievium sp. B.

Sample 369A-38, CC. SI. 1, T16/4.

1. Focus on raised central area.

2. Focus on margin and spines.

Figure 3

Phaseliforma sp.

Sample 369A-37, CC. Sl. 2, H22/3.

Figures 4, 6 Alievium sp. A.

4. Sample 369A-38, CC. Sl. 1, Q16/1.

6. Sample 369A-38, CC. Sl. 1, M43/3.

Figure $5 \quad$ Pseudoaulophacus sp. aff. P. delvallensis.

Sample 369A-38, CC. Sl. 1, T41/0.

Figure 7 Hagiastrin cf. Staurolonchidium tuberosum.

Sample 369A-38, CC. Sl. 1, U17/3.

Figure 8 Spongosaturnalis hueyi.

Sample 369A-38, CC. Sl. 1, J11/2.

Figure 9 Pseudoaulophacus pargueraensis.

Sample 369A-38, CC. Sl. 1, Q16/4. 
PLATE 3
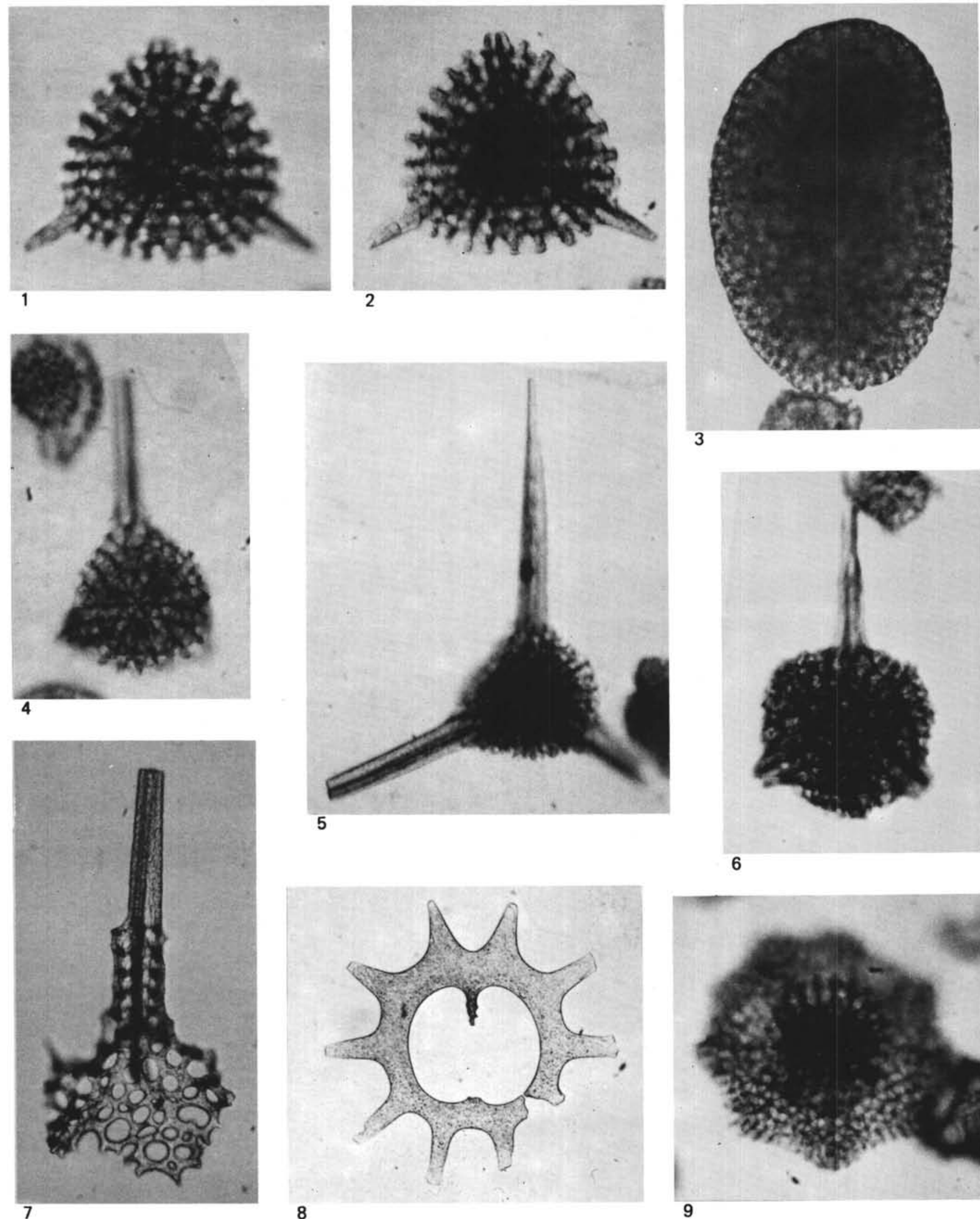

3
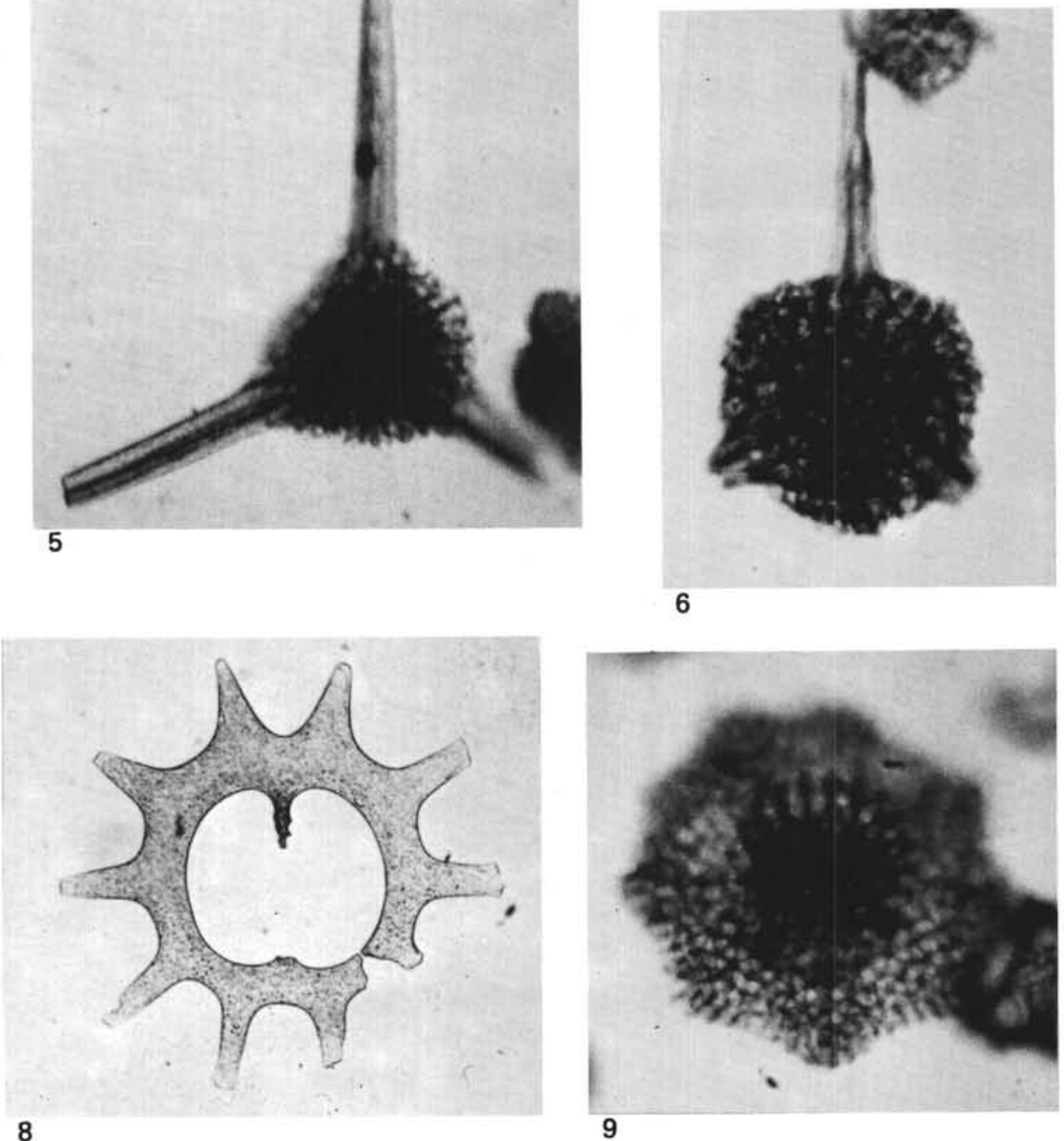


\section{PLATE 4}

All figures are magnified $\times 214$

Figures 1,2 Amphipyndax tylotus.

1. Sample 13A-2-1, 84-86 cm. Fn. 3, K27/4.

Holotype, USNM 243115.

2. Sample 369 A-38-4, 85-87 cm. Sl. 1, C14/0.

Figure 3 Amphipyndax enesseffi.

Sample 369A-39-3, 67-70 cm. S1. 1, E24/3.

Figure 4 Amphipyndax stocki.

Sample 369A-35, CC. S1. 4, T27/3.

Figure $5 \quad$ Amphipyndax plousios.

Sample 369A-35, CC. SI. 4, T24/0.

Figure $6 \quad$ Dictyomitra andersoni.

Sample 369A-38, CC. Sl. 1, K15/0.

Figure 7 Dictyomitra sp. cf. Diplostrobus crassispina.

Sample 369A-36. CC. S1. 5, P23/3.

Figures 8,9 Dictyomitra duodecimcostata duodecimcostata.

8. Sample 369A-39, CC. Fn. 1, M38/4.

9. Sample 369A-39, CC. Fn. 1, Q28/4.

Figure 10 Dictyomitra koslovae.

Sample 369A-39, CC. Fn. 1, N29/4.

Figure $11 \quad$ Lithostrobus punctulatus. USNM 243116.

Sample 369A-38, CC. S1. 1, R18/0.

Figure 12 Lithostrobus litus.

Sample 369A-36-5, 65-67 cm. S1. 1, K27/2.

Holotype, USNM 243117.

Figures 13, 14 Dictyomitra lamellicostata.

13. Sample 369A-38, CC. Sl. 1, E41/0.

14. Sample 369A-38, CC. SI. 1, R16/0.

Figure 15 Stichomitra asymbatos.

Sample 369A-38, CC. Sl. 1, S34/0. 
PLATE 4
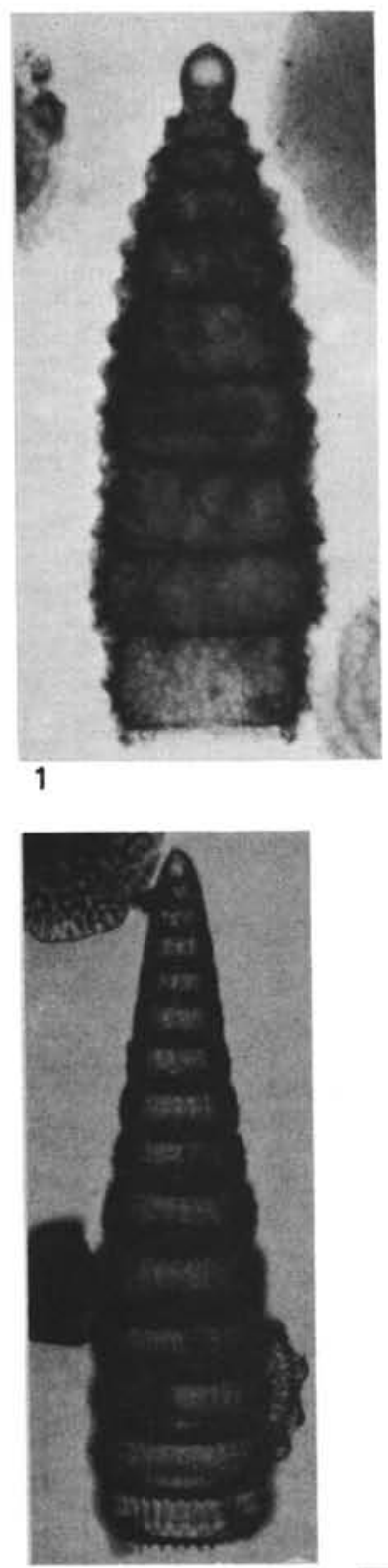

6

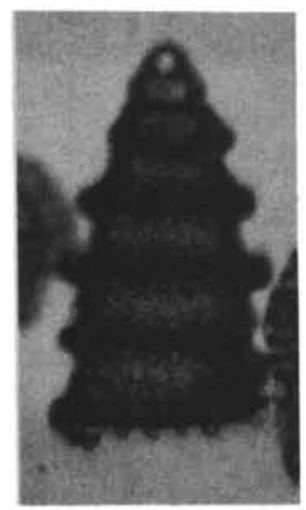

11
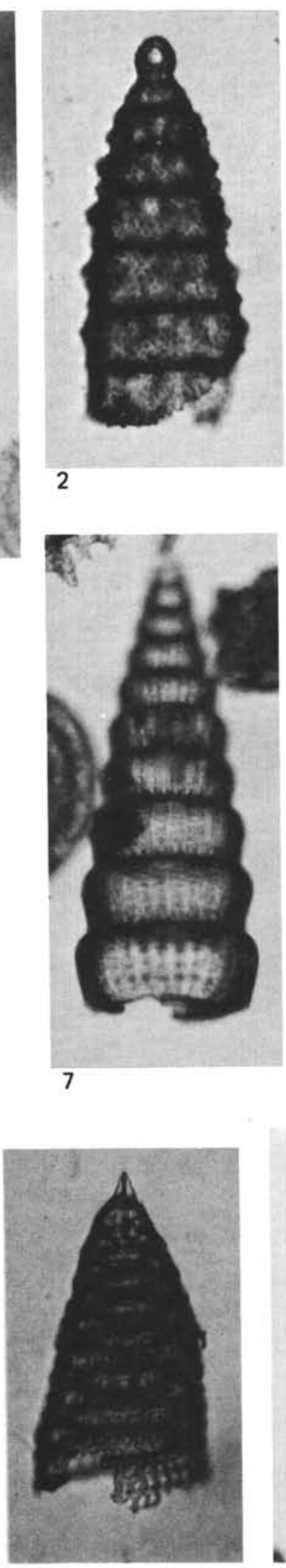

12

13
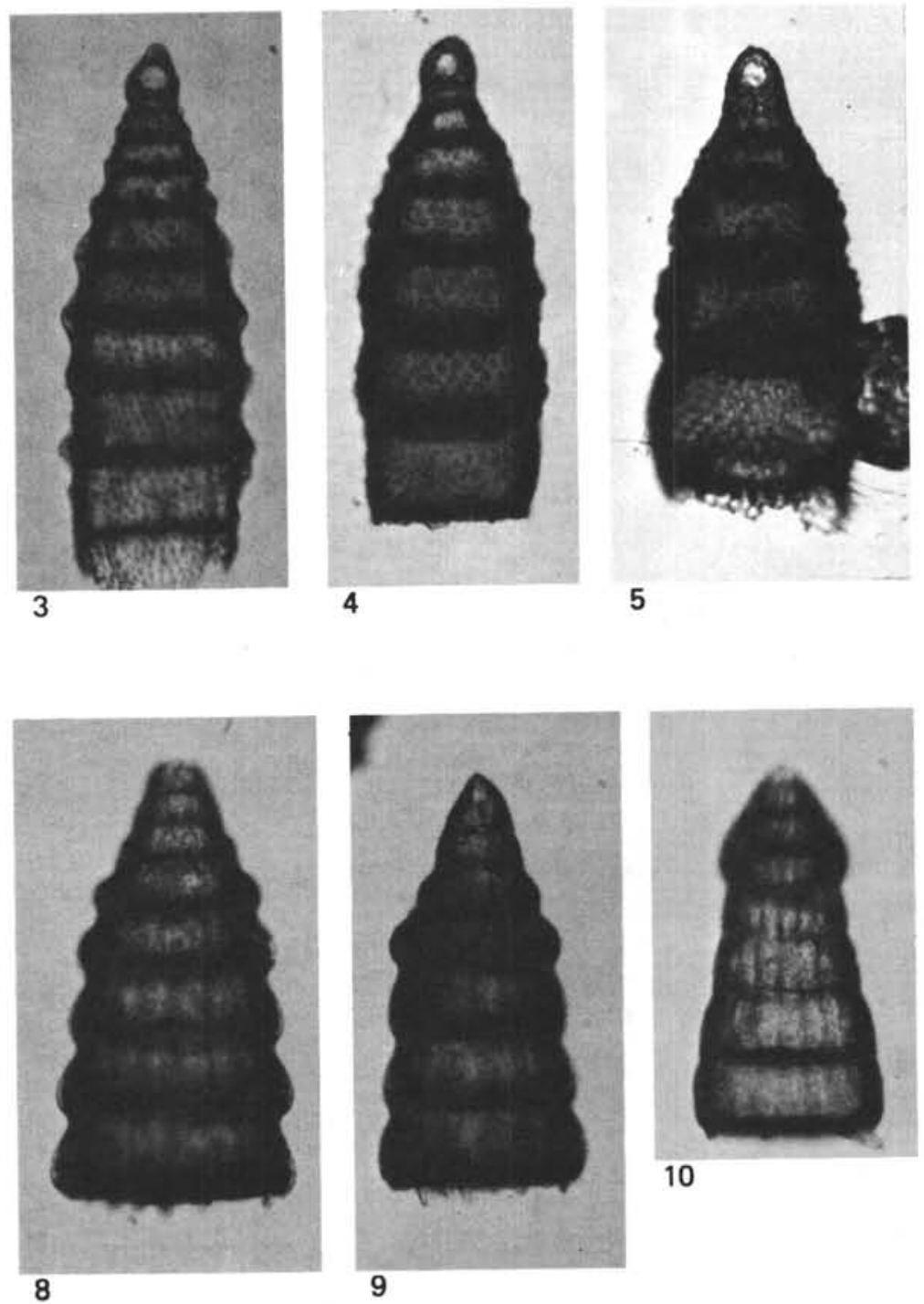

5

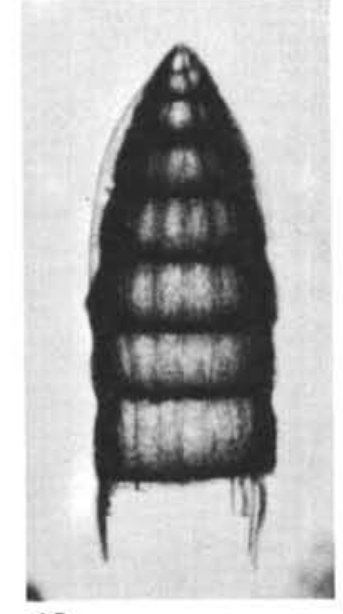

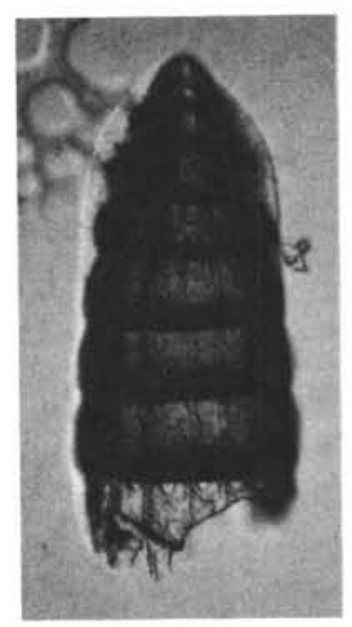

14

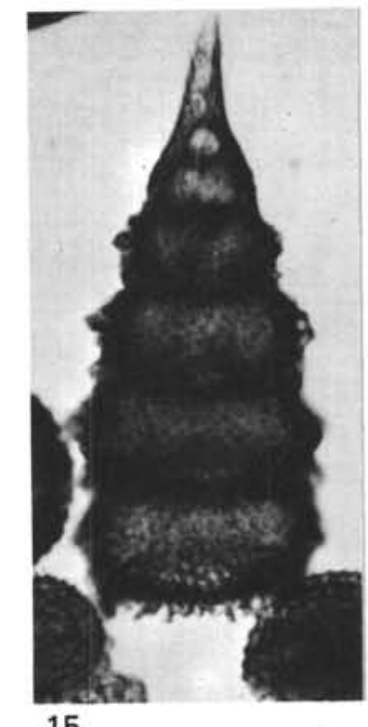


PLATE 5

All figures are magnified $\times 214$
Figure $1 \quad$ Stichomitra sp. aff. S. asymmetra. CAS 39545. St. 1493, S26/4.

Figure 2 Stichomitra asymmetra.

Sample 369A-36-5, 65-67 cm. Sl. 1, O18/4. Holotype, USNM 243118.

Figure 3

Stichomitra compsa.

Sample 369A-35, CC. Sl. 3, P21/0.

Figure 4 Stichomitra manifesta.

Sample 369A-37-4, 65-69 cm. Sl. 1, R34/3. Holotype, USNM 243119.

Figure $5 \quad$ Lithostrobus sp. aff. Lithostrobus rostovzevi.

Sample 369A-39, CC. Fn. 1, N31/1.

Figure $6 \quad$ Cyrtocalpis sp. aff. C. operosa.

Sample 369A-35, CC. S1. 3, D15/2.

Figure $7 \quad$ Theocapsomma teren.

Sample 369A-35, CC. Sl. 4, T33/0.

Figure $8 \quad$ Myllocercion acineton.

Sample 369A-38, CC. Sl. 1, R39/3.

Figure $9 \quad$ Lithomelissa (?) hoplites.

Sample 369A-35, CC. SI. 4, P22/0.

Figure 10 Theocapsomma sp. aff. T. comys.

Sample 369A-35, CC. Sl. 4, T41/1.

Figures 11,12 Theocapsomma comys group.

11. Sample 369A-36-5, 65-67 cm. S1. 1, T24/0.

12. V18-129, $78 \mathrm{~cm}$. St. $1421, \mathrm{~J} 17 / 1$.

Figure 13

Acidnomelos proapteron.

Sample 369A-38, CC. Sl. 1, P30/3. Holotype, USNM 243120.

Figure $14 \quad$ Lithomelissa (?) heros.

Sample 369A-39-1, 75-77 cm. Sl. 1, $\mathrm{O} 28 / 0$.

Figures 15,23 Cinclopyramis sanjoaquinensis.

15. Sample 369A-38, CC. S1. 1, U15/0.

23. Sample 369A-36-5, 65-67 cm. Sl. 1, U28/2.

Figure 16

Figure 17

Figure 18

Figure 19

Figure 20

Figures 21, 22 28

Figure 24

Figure 25

Figure 26

Figure 27

Figure 29
Rhopalosyringium antirrhopum. Sample 369A-35, CC. Sl. 3, P15/2.

Rhopalosyringium sparnon. Sample 369A-35, CC. Sl. 4, J24/4.

Rhopalosyringium colpodes. Sample 369A-35, CC. S1. 4, S22/1.

Clathropyrgus titthium.

Sample 369A-39, CC. Fn. 1, T43/3.

Lophophaena (?) polycyrtis.

Sample 369A-35, CC. Sl. 2, C17/4.

Theocampe apicata.

21. Sample 369A-37-4, 65-69 cm. Sl. 1, F31/4. Ventral view.

22. Sample 369A-37-1, 141-143 cm. Sl. 1, R17/0. Ventral view.

28. Sample 369A-37-4, 65-69 cm. Sl. 1, L32/1. Lateral view.

Afens liriodes.

Sample 369A-37-1, 141-143 cm. Sl. 1, $\mathrm{U} 43 / 0$.

Theocampe bassilis.

Sample 369A-39-3, 67-70 cm. Sl. 1, $\mathrm{R} 34 / 0$.

Theocampe daseia.

Sample 369A-35, CC. S1. 4, T33/0.

Theocampe altamontensis.

Sample 369A-35, CC. Sl. 3, P40/4.

Theocampe lispa.

Sample 369A-35, CC. Sl. 2, N32/0.

Lateral view. 
PLATE 5
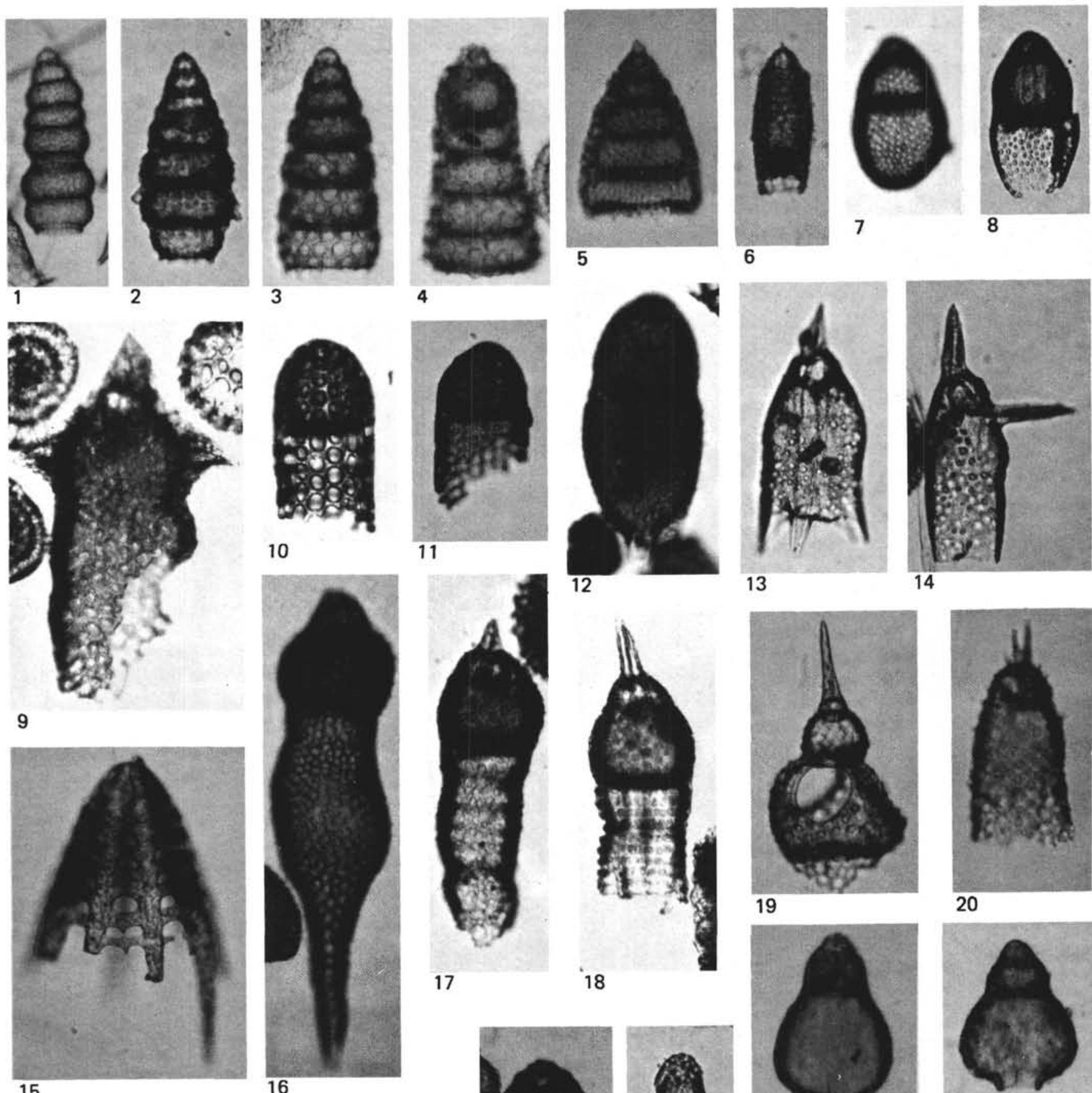

13

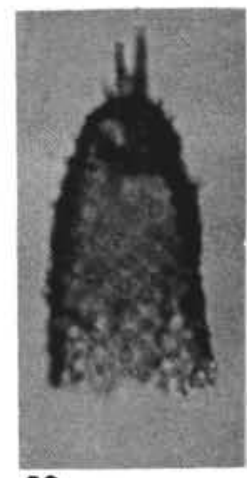

15

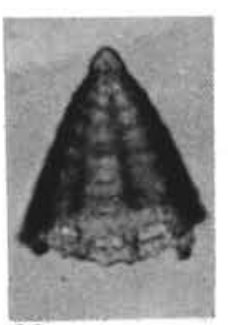

23

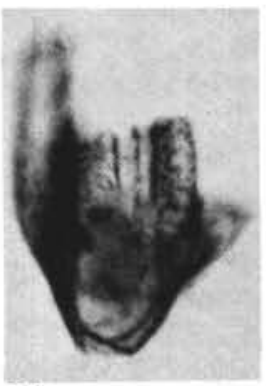

24

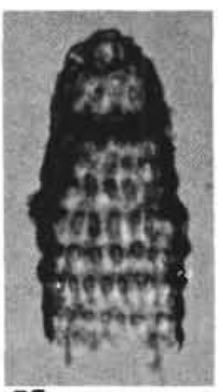

25
17

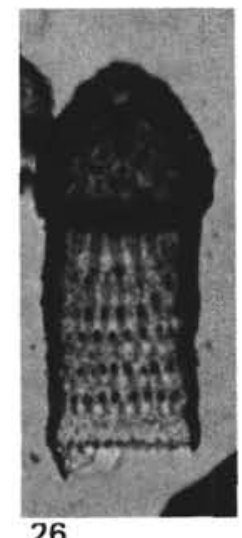

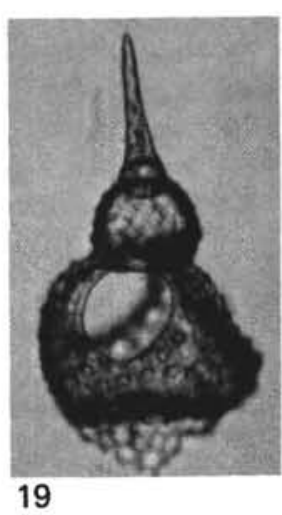

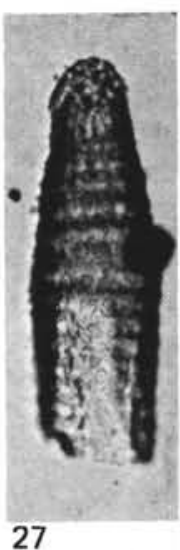

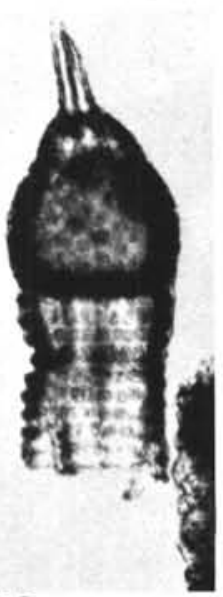

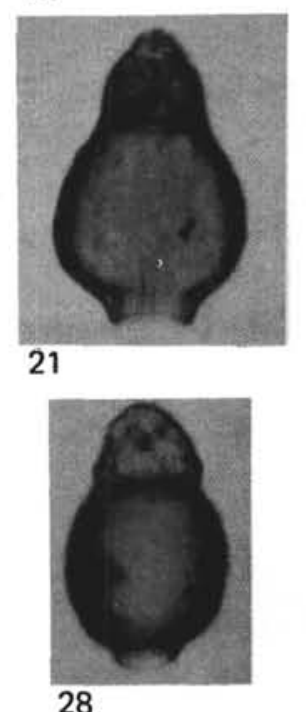

20

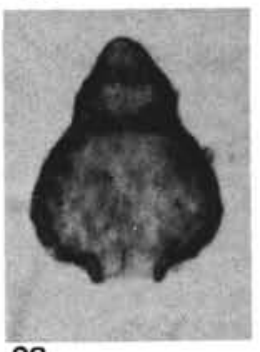

22

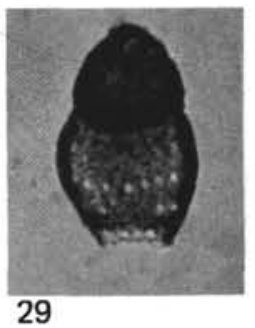

